\title{
A Blueprint for Digital Climate-Informed Advisory Services: Building the Resilience of 300 Million Small-Scale Producers by $\mathbf{2 0 3 0}$
}

TYLER FERDINAND, EMMA ILLICK-FRANK, LOUISE POSTEMA, JIM STEPHENSON, ALISON ROSE, DARKO PETROVIC, CLAUDE MIGISHA, KATIUSCIA FARA, STEPHEN ZEBIAK, TONY SIANTONAS, NICOLETTA PAVESE, TOM CHELLEW, BRUCE CAMPBELL, AND CRISTINA RUMBAITIS DEL RIO

\section{Executive Summary}

\section{Highlights}

- Digital climate-informed advisory services (DCAS) are tools and platforms that integrate climate information into agricultural decision-making.

- Globally, more than 300 million small-scale agricultural producers have limited or no access to DCAS because service provision is still fragmented, unsustainable beyond project cycles, and not reaching the last mile.

- To improve DCAS, six core principles of data quality, equity, co-creation, accountability, sustainability, and scalability should guide investment and service provision.

- The investment required by public and private actors to build the resilience of an additional 300 million small-scale producers via DCAS by 2030 is estimated to be US\$7 billion.

- Returns on investment for DCAS providers range from 1-to-10 to 1-to-70. Returns to farmers in the form of productivity or income average 30 percent and 25 percent, respectively. Co-benefits include enhanced input efficiency, farmer empowerment, and gross domestic product (GDP) growth.

Working Papers contain preliminary research, analysis, findings, and recommendations. They are circulated to stimulate timely discussion and critical feedback, and to influence ongoing debate on emerging issues.

Suggested Citation: Ferdinand, T., E. Illick-Frank, L. Postema, J. Stephenson, et. al. 2021. "A Blueprint for Digital ClimateInformed Advisory Services: Building the Resilience of 300 Million Small-Scale Producers by 2030."

Working Paper. Washington, DC: World Resources Institute. Available online at doi.org/10.46830/wriwp.20.00103. 


\section{Background}

DCAS are tools, platforms, or activities that integrate climate information into agricultural decision-making, helping users adapt to climate variability and change. These services range from digital mobile apps, radio, and online platforms to digitally enabled printed bulletins based on climate models and extension services that utilize climate information platforms. DCAS can help agricultural producers and other value chain actors build resilience to the climate impacts that threaten present and future agri-food systems. However, small-scale producers' access to these services remains limited around the world. Scaling up efforts, while leaving no one behind, is critical to safeguarding the millions of small-scale producers vital to our global food security. Current DCAS efforts are insufficient, marked by fragmented efforts, limited understanding of best practices, and misaligned policy and investment incentives.

\section{Key Findings}

To effectively build the resilience of $\mathbf{3 0 0}$ million smallscale agricultural producers by 2030 through DCAS, a combination of donor, private, and government investment of about \$7 billion is needed between 2021 and

2030. This figure includes both up-front investment costs and annually recurrent costs to maintain service provision. This entails a significant upscaling of current investment levels. Costs are highly dependent on local digital infrastructure and an adaptation-enabling environment as well as the service format. Evidence shows that returns on DCAS investment are high (average 1-to-24) and can drive GDP growth. Producers may see average productivity gains of 30 percent and income gains of 25 percent depending on the product and geography.

To improve DCAS, the six core principles of data quality, equity, co-creation, accountability, financial sustainability, and scalability should guide investment and service provision. These principles were developed through a series of intensive working groups and elaborate upon the example of the Principles for Digital Development. To effectively integrate these principles into DCAS, a more robust knowledge base and improved guidelines and standards are needed.

Investments in DCAS will need to be strategically targeted, embrace diverse business models, and adjust to local contexts. Countries vary greatly in their digital readiness and climate vulnerability. The existing digital and agricultural research ecosystem will determine what will be the best sustainable business model for implementing DCAS (including nondigital means), and vulnerability will dictate the level of urgency and influence prioritization. Targeting and design decisions should be made by national stakeholders through structured participatory processes.

\section{About This Working Paper}

The Global Commission on Adaptation (GCA) was established in 2018 to advance resilience in the face of intensifying climate change by making adaptation central to the global agenda and inspiring and leading ambitious action. Consisting of 35 commissioners and convened by 23 countries, the GCA put forward a goal to build the resilience of 300 million small-scale agricultural producers to climate change by 2030. DCAS offer a great opportunity to realize that objective. This paper lays the conceptual foundation for building the climate resilience of at least $\mathbf{3 0 0}$ million small-scale agricultural producers by 2030 .

The contents of this blueprint were co-created by more than 150 stakeholders organized into three working groups on data quality and governance, equity, and financially sustainable business models. These working groups were led by the International Research Institute for Climate and Society at Columbia University, the World Food Programme, and the World Business Council for Sustainable Development, respectively. In addition to working group reports, this blueprint was developed based on an extensive literature review and expert consultations undertaken by World Resources Institute and the Global Center on Adaptation.

This blueprint aims to

- provide a first estimate for global investment that will be needed to build the resilience of 300 million small-scale agricultural producers by 2030;

- put forward core principles for good practice for DCAS investment, design, implementation, and utilization;

- provide recommendations for how to best target this investment to encourage sustainable, equitable resilience to those small-scale agricultural producers vulnerable to climate change; and

- set the foundation for global and national communities 
of practice to further develop the framework for guiding and targeting investment into DCAS.

\section{Introduction: Digital Climate- Informed Advisory Services Today}

Digital climate-informed advisory services (DCAS) are tools, platforms, or activities that disseminate climate information and help individuals and/or organizations make climate-resilient decisions and adapt to climate variability and change. These services can be digital services, which include mobile apps, radio, and online platforms, as well as digitally enabled services (e.g., bulletins, extension services) for agricultural producers who may not be digitally literate or lack access to digital technologies. These services are meant to support rather than replace personto-person communication channels and strong agricultural extension services. Figure 1 highlights the basic process of producing and delivering DCAS.

Agriculture, food systems, and rural communities-especially small-scale farmers, fishers, and pastoralists, who often lack the resources to adapt-will be severely impacted by climate change. About 570 million small-scale producers worldwide produce 60 percent of global agricultural output (FAO 2017). Most of these producers are in low- and lower-middle-income countries, working and living on farms smaller than five hectares (IFC 2019). The future climate-induced crop losses they will face will be grave and will vary by crop and geography.

Without adaptation, each degree increase in global mean temperature could, on average, reduce global yields of soybeans by 3.1 percent, rice by 3.2 percent, wheat by

\section{FIGURE 1 DCAS Value Chain The adaptation process and its enabling factors}
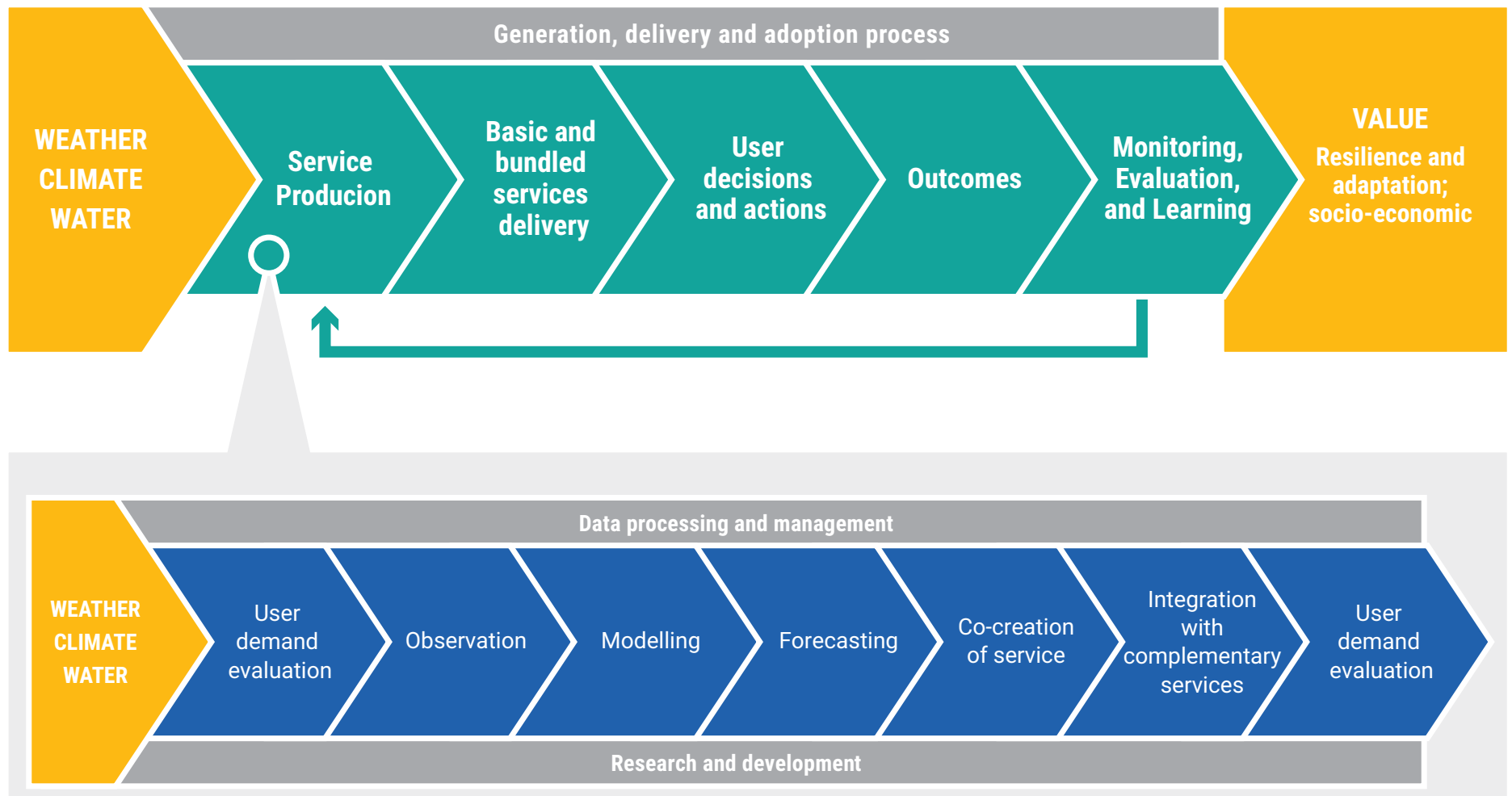

Note: NMHS = national meteorological and hydrological services

Source: Adapted from WMO 2015. 
6.0 percent, and maize by 7.4 percent (Zhao et al. 2017). India already has seen wheat, rice, and maize decrease by 5 percent, 6-8 percent, and 10-30 percent, respectively (Aryal et al. 2020).

The World Food Program projected that an additional 121 million people in the world's poorest countries could fall into acute food insecurity as a result of the COVID-19 pandemic (FAO et al. 2020; WFP 2020). Climate change and variability are leading causes of rising global hunger, making productivity and resilience at the individual level even more essential for global food security (FAO et al. 2018). New strategies are needed to achieve the $25-70$ percent increase in crop production required to feed the world's growing population by 2050 (Hunter et al. 2017).

DCAS offer crucial opportunities to build the resilience of small-scale producers in the face of climate change, particularly when bundled with complementary services (e.g., financing, input supply, market access, insurance). From seasonal forecasts to pest advisories, effectively designed DCAS can provide producers with the resources to adapt to climate shocks and plan for new climate conditions. Consequently, small-scale agricultural productivity and household income can substantially increase, with an average of 30 percent and 25 percent, respectively (see Appendix B for figures). In addition, DCAS result in enhanced risk mitigation; farmer empowerment; and wider environmental, economic, and development benefits. Figure 2 provides an overview of the DCAS ecosystem and the types of actors and services that are involved.

Although DCAS are expanding, demand is still not being effectively met. According to the Global System for Mobile Communications (GSMA), there were 184 digital agriculture advisory services in Sub-Saharan Africa, 56 in South Asia, 31 in Southeast Asia, and 11 in Latin America and the Caribbean as of January 2020. Less than half of those explicitly provide climate-related advisories (GSMA 2020). Simultaneously, the number of active users for existing agricultural services is only 15-30 percent of those registered (based on Tsan et al. [2021] estimates in Africa). ${ }^{1}$ Other regions lack similar analysis but have similar gaps in engagement, particularly for women (Kristjanson et al. 2017). More than 15 countries have cited a need for climate-informed advisory services in their latest nationally determined contributions (NDCs) (Ongus 2020). Some national governments, such as Ethiopia, are already scaling DCAS (Seid et al. 2019). Without scaling DCAS in a financially sustainable, equitable, effective, and reliable manner, we risk reinforcing a divide where communities with resources benefit from digitalization and vulnerable, under-resourced communities are left behind.

The nexus between digital readiness and climate vulnerability provides one way of evaluating DCAS challenges, needs, and opportunities. Figure 3 shows a preliminary snapshot of countries, showing those more capable of addressing climate change through digital means (e.g., much of Latin America), those requiring substantial digital infrastructure investments to address high vulnerability (e.g., much of Sub-Saharan Africa), and those lacking essential data to understand the current enabling environment (e.g., Sudan). To appropriately target investments and efforts, metrics should be evaluated on a case-by-case basis at a higher resolution than the displayed national level.

In line with the goal of the Global Commission on Adaptation (GCA), this blueprint charts the conceptual foundation for building the resilience of $\mathbf{3 0 0}$ million small-scale agricultural producers with DCAS by $\mathbf{2 0 3 0}$. It builds upon emerging best practices and opportunities to improve DCAS. Globally, 150 million lower-endowment farmers (i.e., artisanal, low input, minimal market integration, high food insecurity) and 150 million conventional small-scale farmers (i.e., nonartisanal, low-to-medium input, limited market integration, variable food security) are less likely to be digitally connected than larger-scale and commercial farmers (Steiner et al. 2020). Figure 4 provides an overview of their geographical distribution.

This DCAS blueprint is a product of collaboration between the World Resources Institute (WRI), the Global Center on Adaptation, the World Business Council for Sustainable Development (WBCSD), the World Food Programme (WFP), and the International Research Institute for Climate and Society (IRI) at Columbia University. Qualitative content in this report was co-created by three iterative working groups on data quality and assurance (led by the IRI), equity (led by WFP), and sustainable business models (led by WBCSD). These working groups included more than 75 experts from 57 institutions (see Appendix A for a full list of organizations). Quantitative analyses based on expert consultations and literature reviews were conducted by WRI and the Global Center on Adaptation. 


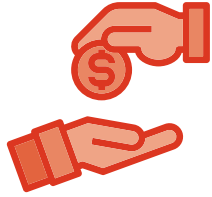

BUSINESS TO INTERMEDIARY

Solutions that are sold to agribusinesses, insurers, or banks that pay for their customers' access.

Example: aWhere

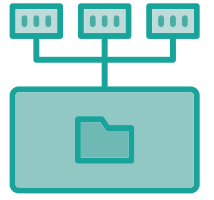

\section{COMPLEMENTARY SERVICE PROVISION}

Services that integrate, or bundle, with DCAS to provide solutions for building resilience (see examples of bundled services).

Example: Pula Advisors

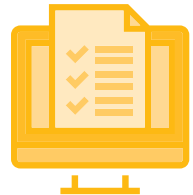

\section{EMBEDDED WITHIN COMMERCIAL OPERATIONS}

Solutions applied within commercial operations

and supply chains of agribusinesses. Intermediary service providers may be paid for some of the services required for digital climate-informed advisory services (DCAS) development.

Example: Olam

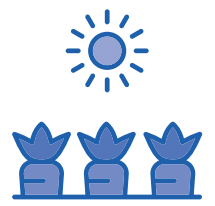

SERVICES SUPPORTING NATIONAL AGRICULTURAL ADVISORY SYSTEMS

Services typically led by nongovernmental organizations or academic institutions to help integrate climate information into existing training, extension services, farmer field schools, and so forth.

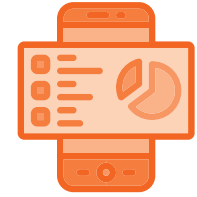

\section{SPECIALIZED INTERMEDIARY SERVICES}

Services that help DCAS operate effectively, including platforms, data managers, or cloud-based support.

This is a more recent phenomenon, making it difficult to assess its scale.

Example: Climate Edge

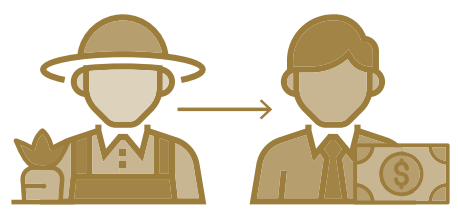

"SUPER PLATFORMS"

Services that link farmers to buyers and finance, advice, and other services. Here, intermediaries are eliminated. ${ }^{a}$

Example: Farm to Market Alliance
Example: Plantwise
POTENTIAL ACTORS

- Tech providers

- Agritech companies

- Mobile network operators

- Nongovernmental organization/

international nongovernmen-

tal organizations

- Academic institutes

- Governments

- Multilateral organizations

- Enterprise solution providers
INFORMATION TYPE

- Weather and climate forecasts

- Agroclimatic information

- Smart advisory (i.e., advice on the types of crops to grow and appropriate application of inputs)

- Pest and disease management

- Early warning system advisories
EXAMPLES OF BUNDLE OPTIONS

- Mobile banking and finance

- Insurance

- Input services

- Health services

- Market access and prices information

- Product verification and traceability

- Record keeping

- Shared assets management
DELIVERY

TECHNOLOGIES

- Interactive voice response

- Unstructured supplementary service data

- Short messaging service (SMS)

- Web

- Chat and chatbots

- Apps

- Radio

- Television

- Bulletins

- Self-help groups

- Extension agents

Note: ${ }^{\text {a }}$ Tsan et al. 2021.

Source: Based on information from the Bill \& Melinda Gates Foundation (unpublished) and Phatty-Jobe et al. 2020. 


\section{FIGURE 3}

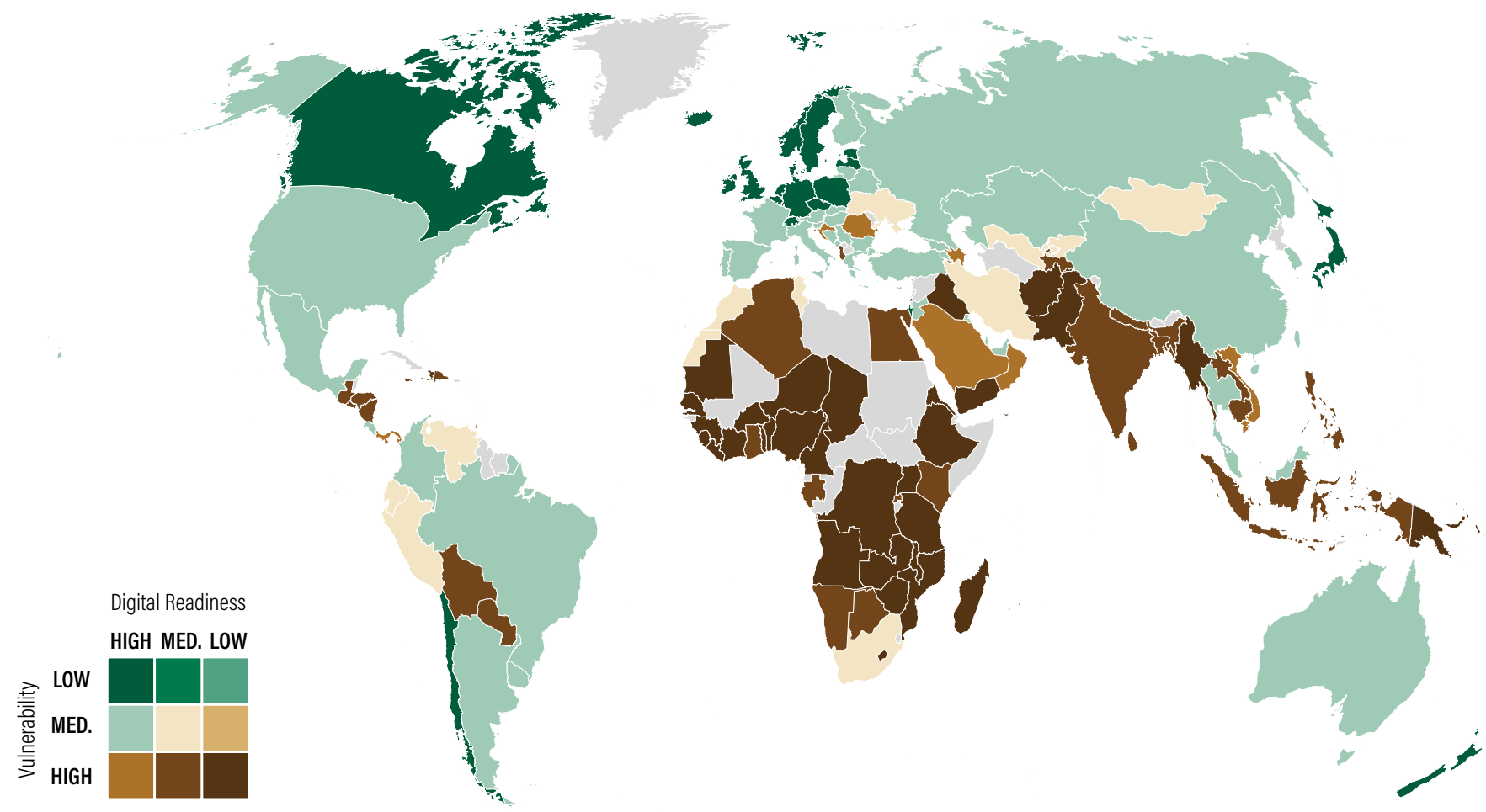

Sources: ND-GAIN 2020, CISCO 2020 and WRI authors.

\section{FIGURE 4}

Global Distribution of Small-Scale Conventional and Lower-Endowment Farmers as Percentage of Regional Agricultural Labor Force

Conventional small-scale farmers (\% of total farms)

$0 \%$

$0 \%$

10

20

$7.7 \%$

South Asia
Lower-endowment small-scale farmers (\% of total farms) 30

\section{$62.1 \%$}

Jub-Saharan Africa $16.7 \%$

East Asia \& Pacific

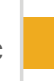

Middle East and North Africa

Latin America and the Caribbean

\begin{tabular}{|r|r|r|r|}
\hline \multicolumn{3}{|c|}{$16.7 \%$} & \\
\hline & & & \\
\hline & & & \\
\hline & & & $33.3 \%$ \\
\hline & & & \\
\hline & $19.0 \%$ & $9.5 \%$ & \\
\hline
\end{tabular}

Source: Based on Steiner et al. 2020. 
This blueprint aims to build a conceptual foundation for DCAS investment and implementation over the next 10 years by

- estimating the required investment needs to build the resilience of 300 million small-scale agricultural producers with DCAS by 2030;

- putting forward foundational principles for implementing accurate, equitable, co-created, accountable, financially sustainable, and scalable DCAS; and

- setting the foundation for global and national communities of practice to further develop the framework for guiding and targeting investment into DCAS.

\section{Global Investment Needed by 2030}

To effectively build the resilience of $\mathbf{3 0 0}$ million smallscale agricultural producers by 2030 through DCAS, we need $\$ 7$ billion in donor, private sector, and government investment between 2021 and 2030 (see Appendix $B$ for details). This investment would cover up-front costs and the annual recurrent costs of specific services-based upon estimated growth trends of service provision-to reach 300 million producers by 2030. It would not cover investments in infrastructure and enabling environments.

Several challenges make it difficult to determine the overall investment needed to build the resilience of 300 million producers with DCAS by 2030: highly limited data on project costs; vast differences between projects in terms of service provision, necessary training, and infrastructure costs; regional variances in the up-front costs for infrastructure, knowledge, and enabling environments; and large differences in farmers reached per project, with generally lower costs per farmer for bigger projects. Given these challenges and limitations, the figures reported in this blueprint are an approximation, used primarily to highlight the substantial investment that will need to be addressed to develop and scale effective DCAS to reach the most vulnerable producers worldwide. The blueprint sets out a call to action for public and private sector stakeholders, donors, and others within this ecosystem to further develop the investment case and the enabling environment needed for it to be targeted successfully. In Appendix B, Table B2 shows the projections used to obtain the total estimated global investment figure.

The past five years of DCAS investments provide some indication of the additional investment and scale needed to build the resilience of 300 million small-scale producers by 2030. Figure 5 shows the spread of investments in DCAS from international donor organizations, philanthropies, and donor governments (Appendix B includes a donor list).

These country-specific investments from 2015 to 2020 total over $\mathbf{\$ 1}$ billion. Generally, data are not available for the number of producers reached with these investments because DCAS are often one part of a larger project.

Figure 6 provides a summary of some of the major cost categories of DCAS, with examples of promising efforts that are either addressing or reducing these costs. Box 1 provides an example of the costs from a DCAS provider. 


\section{FIGURE 5 Investments in DCAS by Country}

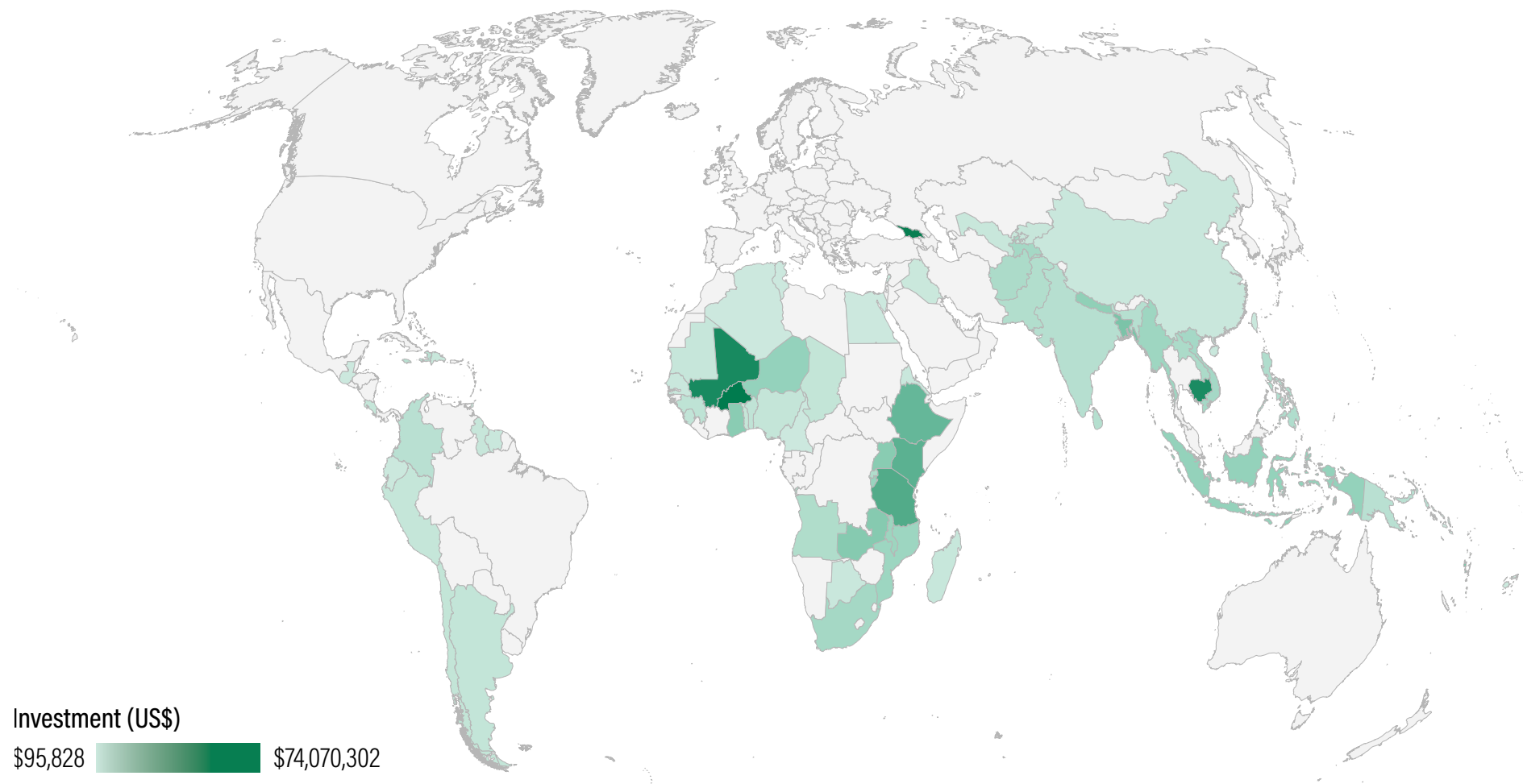

Notes: These data are based on numbers that were provided directly from organization focal points or organizational project portfolio databases. These figures do not account for private capital investment for digital climate-informed advisory services, which has not been adequately tracked. See Appendix B for methods.

Source: WRI authors. 


\section{FIGURE 6 Cost Categories for DCAS}

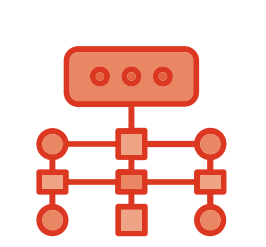

NFRASTRUCTURE
NATIONAL METEOROLOGICAL AND HYDROLOGICAL SERVICES

- Public investment programs in expanding and improving national meteorological and hydrological services (NMHS) infrastructure and capability

- Development and application of technology such as satellite data, drone data, commercial microwave links for rainfall observations, and to complement or fill in missing station data

- Example: Systematic Observations Financing Facility

\section{TELECOMMUNICATIONS}

- Public and private investments in digital infrastructure

- Regulatory reforms

- Example: Global System for Mobile Communications

(GSMA) estimates of mobile operator infrastructure costs

\section{GOVERNMENT LEADERSHIP}

- Regional and global platforms to collectively raise the profile of this issue on domestic and global agendas

- Example: International Digital Council for Food and Agriculture of the Food and Agriculture Organization of the United Nations

\section{HUMAN-CENTERED, CO-CREATION PROCESSES}

- Development and application of co-creation processes and inclusive human-centered design

- Example: Participatory Integrated Climate Services for Agriculture (PICSA) ${ }^{a}$

\section{INSTITUTIONAL READINESS}

- Institutional capacity building for understanding of how to produce, disseminate, and apply digital climate-informed advisory services (DCAS)

- Example: Climate for Development in Africa Programme
STANDARDS, PROTOCOLS, AND REGULATIONS

- Development and application of standardized global protocols and model regulations

- Examples: see Appendix C for a collection of existing standards and protocols for climate data

\section{PARTNERSHIP DEVELOPMENT}

- Dedicated resources for intermediation to help partnerships form more efficiently

- Example: Mercy Corps' Agrifin

\section{TECHNOLOGY DEVELOPMENT AND MAINTENANCE}

- Creation and maintenance of software

- Payment for intermediary services

- Example: Digital Public Goods Alliance and FarmStack

\section{VALIDATION OF SIMULATION MODELS}

\section{DEVELOPMENT AND START-UP COSTS}

- Iterative updates and validation

- Investment in automated data collection and sensors

- Example: Agricultural Model Intercomparison and Improvement Project
ENUMERATION AND REGISTRATION OF FARMERS

- Identifying, counting, and registering farmers for DCAS

- Example: First Aadhar Authenticated Digital Farmers Database

\section{MONITORING AND EVALUATION OF DCAS INPUTS AND OUTPUTS}

- Field trials, lab tests, user experience, and so forth related to agricultural research that informs DCAS

- Evaluation of DCAS impacts

- Example: Digital Green ${ }^{\mathrm{b}}$

Note: For elaboration on examples, please see Table D1; a. See Box 2; b. See Box 5.

Source: WRI authors. 


\section{Box 1 | Example of Costs from a DCAS Provider: aWhere}

\section{Aim:}

- Enable data-driven decisions related to weather forecasts and climate information

\section{Target users:}

- Global (e.g., Bloomberg, World Bank Group)

- National (e.g., Honduras, Kenya)

- Companies (e.g., Econet, EOS, Esoko, Netafim)

\section{Dates:}

- 1999-present

\section{Overview}

aWhere is a benefit corporation that provides in-time, accurate, and complete weather data to a wide range of organizations, offering over 1.9 million complete virtual weather stations that can drive crop and hydrology models, making local weather data accessible to farmers.

\section{Costs}

Services can be provided at a seasonal cost of five dollars per farmer (see Figure B1.1 for cost breakdowns). Governments can pay scaling-up services, given high returns for farmers. Mobile network operators wanting to retain customers by offering personalized services can pay to bring farmers into digital platforms. Crop modeling and analytics are best developed by government agriculture research and paid from extension budgets or by agri-input providers wanting to offer a premier service. The most expensive component is short message service (SMS) delivery costs. Mobile network operators can contribute here through discounted SMS rates.

\section{Lessons}

- Service management involves clearly defining the roles of private and public sector actors, clarifying expectations, and building mutual accountability. This is the most challenging and important component to provide value to users and develop models to cover transaction costs.

- Once trust and operational efficiency are established, more complex service delivery models can be developed, instead of starting with complex services.

- Weather-based recommendations can increase yields by over 30 percent and deliver a return on investment of over 1:14 for tservice providers.

\section{FIGURE B1.1 | aWhere Cost Breakdown}

Source: aWhere.

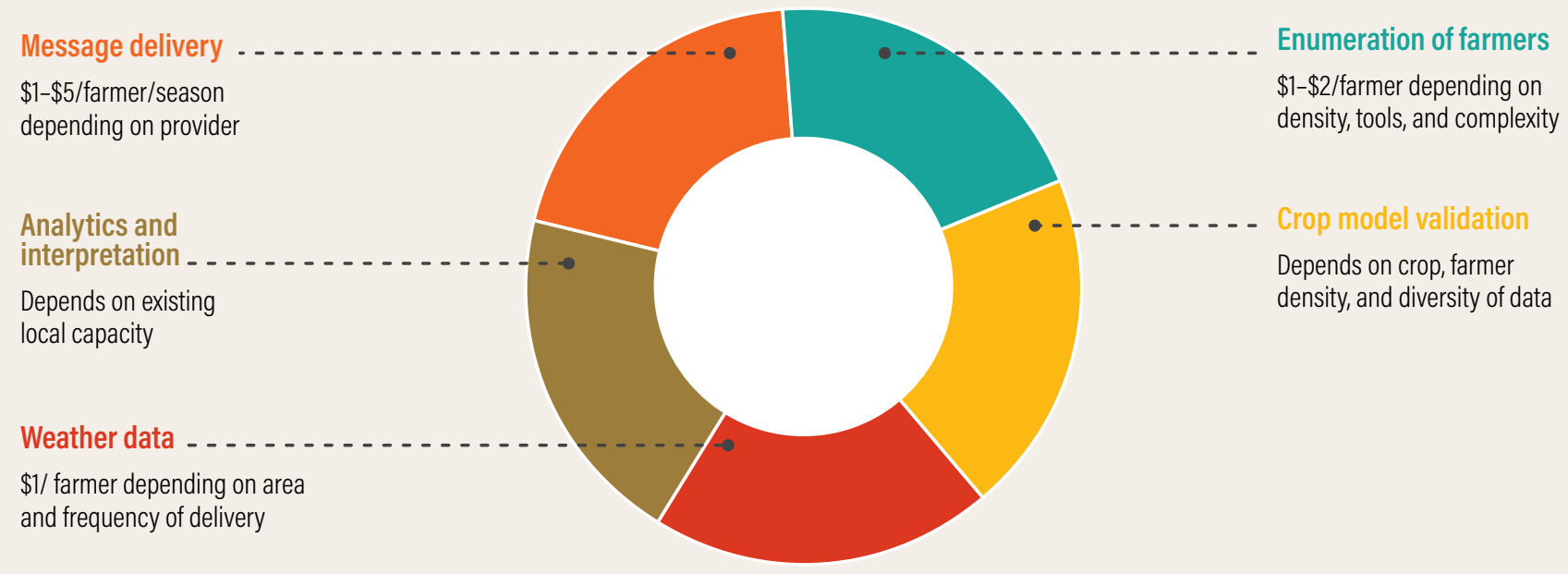




\section{Benefits and Potential Return on Investment}

To make good investment decisions, one must understand the benefits and returns of investments to stakeholders. since the marginal costs of disseminating information are close to zero for some forms of services (e.g., mobilebased extension systems), much is to be gained from investing in and scaling DCAS (Fabregas et al. 2019).

Table 1 presents the types of returns on investment (ROIs) that can be expected from investing in DCAS for smallscale producers and for the larger economy.

\section{TABLE 1 Different Components of Benefits and Returns on Investment for DCAS}

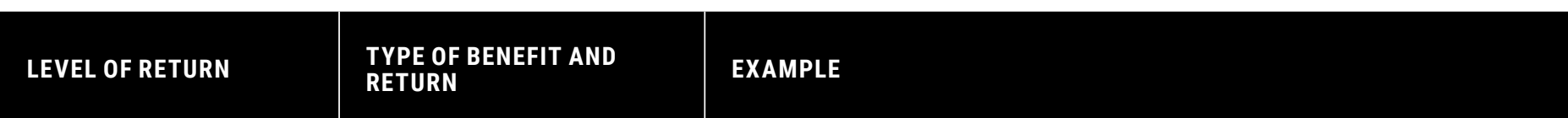

\section{Small-scale agricultural Yields and income producer}

Reduced risk

Input efficiency

Knowledge and empowerment
Various projects around the world have shown productivity gains of

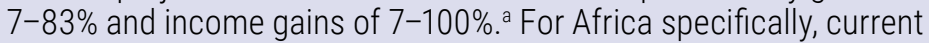
estimates based on around 50 projects suggest that digital climateinformed advisory services (DCAS) can increase yields $23-168 \%$ and incomes $30-57 \%$, with the highest increases for bundled services. ${ }^{b}$

A study of 15 Agro-Meteorological Field Units in India from 2003 to 2007 showed that participating farmers had a $10-15 \%$ increase in yield and a $2-5 \%$ reduction in costs compared to farmers not using the service. Farmers reported that forecasting of rainfall and other weather indicators help to better prepare and manage potential losses related to variable rainfall and pests/diseases. ${ }^{\circ}$

Evaluation of risk reduction in terms of avoided or mitigated risks is extremely rare due to a lack of counterfactuals. Often, it is a core assumption in services' theory of change.

Various projects have shown efficiency gains up to $30 \%$ for seeds, up to $20 \%$ for fertilizer and pesticides, and up to $15 \%$ for water usage. ${ }^{d}$

By its very nature, well-designed DCAS are meant to promote the agency of farmers as decision-makers in the face of climate change by providing actionable information. ${ }^{e}$

In regions with high network connectivity, such as Australia, Europe, and the United States, the cost-benefit rates of using meteorological services in agriculture are generally between $1: 3$ and $1: 10{ }^{f}$

Even though up-front investments in developing countries are higher due to poorer infrastructure connectivity, high ROls of the entire projects are still observed. Examples include cost-benefit ratios of 1:48 for the Satellite-Assisted Pastoral Resource Management in Ethiopia, 1:10 for the Precision Agriculture for Development program in India, and up to 1:70 for aWhere in Kenya. Furthermore, eChoupals in India has an average 32.3\% ROI per year. ${ }^{9}$

Rodrigues et al. (2016) modeled an average annual increase of 20.8 to 173.7 USD $\$$ million in national GDP based solely on the use of weather services across Kenya, Malawi, Mozambique, Tanzania, and Zambia.

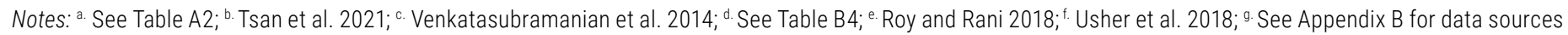
and calculations.

Source: Authors 


\section{Six Principles Fundamental for DCAS Success}

Multiple working group sessions distilled the top nine challenges to creating DCAS that are sustainable while producing resilient and equitable outcomes (see Table 2).

Beyond increasing investment in services, addressing these challenges requires a fundamental change in practice norms. This section presents six core principles to guide how to scale DCAS successfully, in terms of number of producers reached, ROIs, equitable access and the quality of services delivered. The DCAS principles aim to inform new DCAS investment and development, based on the collective experiences from the 57 participating organizations (see Appendix A). They were developed recognizing the Principles for Digital Development, endorsed by organizations including the Bill \& Melinda Gates Foundation, WFP, Mercy Corps, and more.

TABLE 2

DCAS Priority Challenges

\section{CHALLENGES}

There is a lack of consistent standards for data provenance and validation of digital climate-informed advisory services (DCAS). Transparent model benchmarking based on agreed-upon performance indicators is critical to compare and improve services. ${ }^{2}$ Transparent (or open) data are essential for validation, interoperability, and providing noncost services to those most in need. Concerns about confidentiality, intellectual property rights, and data security must be addressed. ${ }^{b}$

DCAS is neither equitably accessible nor usable. Users have different needs, resources, and knowledge, and to maximize the benefits of DCAS, service design must also focus on those currently marginalized (e.g., women, youth, disabled individuals, indigenous people). Key considerations include user costs, design, content, communication channels and methods, and providing additional support.

DCAS is often supply driven rather than demand driven and fit for purpose. This undermines the effectiveness of DCAS and their adoption by users. Consequently, services will not be financially sustainable once donor subsidies are removed. ${ }^{\circ}$ Demand should be evaluated from both the perspective of farmers and governments.

DCAS project and program timelines and budgets often do not accommodate for design and implementation strategies that promote financially sustainable, equitable, or scalable impacts. Co-creation as an iterative process can take additional resources and time. Without investment in co-creation and equitable services delivery, demand for services may dwindle, resulting in unsustainable services over time.

Current monitoring, evaluation, and learning (MEL) and evidence generation strategies are not adequate to improve future DCAS. Developing metrics and methodologies for assessing the impacts of DCAS is critical but difficult due to inadequate MEL. Concrete evidence is limited regarding the costs, returns on investment, resilience building, and efficacy of advisory application against counterfactuals, partly caused by a lack of tracking of investments, especially by donor organizations.

There is a lack of digital readiness in many countries needing DCAS most. Certain levels of digital literacy are required to effectively apply DCAS, especially those using newer technologies.

DCAS providers are not always transparent about procurement processes, partners' roles and responsibilities, model uncertainties, and sponsorship arrangements or advertising. This harms user and partner trust. Transparency is essential for building a common understanding of objectives and outcomes and establishing accountability.

The private sector is often not incentivized to engage in public-private partnerships (PPP) for DCAS due to the high costs associated with wide-scale producer engagement. Governments can create the enabling environment for innovative DCAS PPP models. Public/ international investments in research and development capital can support private parties to codesign PPP projects with public partners. Evidence generation on benefits can encourage private sector engagement and buy-in for DCAS policies.

Notes: a. EIP-AGRI 2017; b. Sara 2019; c. Norton and Alwang 2020.

Source: Authors. 


\section{Data Quality and Assurance}

Climate service data quality is the extent to which a data product meets the needs of the users, including the level of accuracy and the degree to which it is fit for purpose.

Quality assurance refers to the processes through which the quality of products and services are communicated, including to users (Larosa and Perrels 2017).

The use and acceptance of existing relevant standards and governance principles is key to ensuring data quality. A lack of data quality or sufficient governance decreases the ability of DCAS to support farmers and erodes farmers' trust and use of advisory services. Moreover, data quality problems may affect farmers' decisions and hurt their livelihoods. An example of good data quality and assurance is provided from Rwanda, using the IRI's Enhancing National Climate Services (ENACTS) initiative, shown in Box 2. Key components of data quality and assurance are highlighted in Figure 7.

\section{Promote Equity}

Equity in DCAS means ensuring that women, youth, the under-resourced, disabled, and socially marginalized groups are equally served by advisories according to their intersectional needs (e.g., those relating to their identity, experiences, and environment). This includes those who may not have access to digital tools. It also speaks to the degree to which disadvantaged groups affect design

\section{Box 2 | Example of the Principle of Data Quality and Assurance in Practice}

\section{Project Title:}

- Rwanda Climate Services for Agriculture

\section{Aim:}

- Enhance access, understanding, and incorporation of climate information (historical and seasonal forecasts) into management decisions of small-scale farmers

\section{Country:}

- Rwanda

\section{Dates:}

- 2015-present

\section{Overview}

This initiative provides locally actionable climate information for farmers and other agricultural decision-makers. It was used to build the capacity of the Twigire Muhinzi national agricultural extension service and other intermediaries to communicate climate information with farmers and support farmers' risk management decisions using a set of participatory tools.

\section{Key features}

In this initiative, interactive radio programming, radio listener clubs, and short message service (SMS) complemented the faceto-face Participatory Integrated Climate Services for Agriculture (PICSA) process, particularly for weather forecasts. Adapting the International Research Institute for Climate and Society's Enhancing National Climate Services (ENACTS) approach, extension personnel use interactive online "map rooms" where users can analyze, visualize, interpret, and download location-specific climate information products. Afterward, the map rooms can be transferred to farmers using PICSA. ENACTS also facilitates integration of resources from the national meteorological and hydrological services and supports the elimination of data gaps by merging quality-controlled station observation data with proxy data from satellites and climate model reanalysis products.

\section{Lessons}

- Digital technologies overcome bottlenecks to the availability and accessibility of the climate information needed to support farmer decision-making.

- ENACTS allows for the reconstruction of past and generation of future high-quality climate data and the development of localized analysis and forecasts.

- ENACTS allows for the integration of data from multiple sources that enhance data quality.

Note: See Appendix D for the list of relevant service actors.

Source: Based on Birachi et al. 2020. 


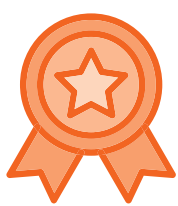

\section{USE OF INTERNATIONAL DATA QUALITY STANDARDS}

Data standards play a crucial role in supporting quality and building trust. Currently, many different standards-targeting different sections or sources of information-exist. ${ }^{\text {a }}$ Quality standards should incorporate regulations around intellectual property and privacy that protect service designers/providers and users alike.

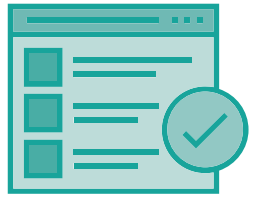

\section{RIGOROUS VALIDATION OF DATA AND RELATED ANALYSES}

Significant concerns about the accuracy of digital climate-informed advisory services (DCAS) data can best be addressed through rigorous evaluation against quality-controlled measurements, like the valuation of weather and climate predictions. This is also essential for agricultural data that requires ground truthing. Agricultural production benchmarking can guide quality management by identifying best practices against which to measure shortcomings. ${ }^{\circ}$

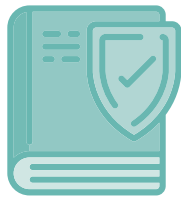

\section{IMPLEMENTATION OF DATA MANAGEMENT GUIDELINES}

Properly managed data allows for validation, comparison, and/or interoperability. This includes making data open and accessible whenever possible.

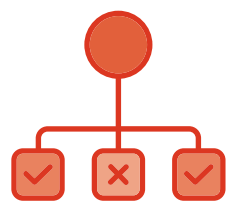

\section{ENHANCED RESOLUTION FOR LOCALIZED DECISION-MAKING}

The availability of plot-level information is extremely limited, requiring creative solutions that involve the Internet of Things, cloud computing, and farm-level automated weather stations. Emnotion uses statistical programming and machine learning in combination with virtual weather stations to provide farmers with hourly updates at up to 100-by-100-meter resolution. ${ }^{\text {. }}$

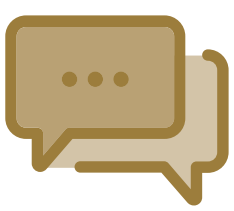

\section{TRANSPARENT COMMUNICATION OF INFORMATION ACCURACY AND UNCERTAINTY}

Where data uncertainties exist, it is important to communicate these gaps to avoid mistrust of information. For example, the International Research Institute for Climate and Society's Climate Predictability Tool reports on the predictive skill of forecasts during particular periods of the year to optimize risk management and decision-making. ${ }^{b}$

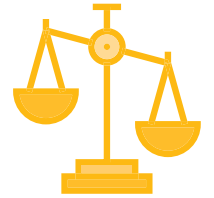

\section{ESTABLISHMENT OF LAWS AND REGULA- TIONS THAT GOVERN DATA ACCESS, INCLUDING OPEN ACCESS TO PUBLIC DATA}

Improved policies for data governance should consider multidisciplinary working groups, data trusts, data cooperatives, humanitarian licensing, and social certification schemes.

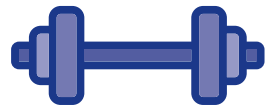

\section{CREATION OF STRONG NATIONAL DCAS SYSTEMS}

This will require new interagency institutional arrangements (e.g., coordinating climate services and agriculture departments), enabling policies (e.g., interoperable data between relevant sectors), and shared resources to prevent counterproductive competition.

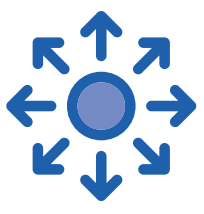

\section{EXPANSION OF EXISTING OPEN PLATFORMS}

Avoid generating new data sets that may be redundant, contradictory, or noninteroperable.

Notes: a. See Appendix C; ${ }^{\text {b. }}$ Barnston and Tippett 2014; c Knox et al. 2013; d. IBM 2019.

Source: Authors. 
and governance of services. Cultural and gender norms may influence decision-making authority and differentiated access to assets, including land, financial credit, and technology (Gumucio et al. 2020). When services do not effectively target the needs of both men and women, they can reinforce existing gender-based inequalities (Carr and Onzere 2017; Perez et al. 2015). Figure 8 depicts the building blocks for the equity principle. The featured Mongolian case study (Box 3) highlights how users can further understand their needs during the design process.

\section{Co-create with Stakeholders}

Co-creation of climate services brings together the producers of weather and climate information with those who use the information to make decisions - often with intermediaries to connect these actors - to solve a problem where weather and climate information is relevant. Co-creation is explicitly nonextractive and not designed to be a means to an end (i.e., the product) but instead as an opportunity to build capacity and empower stakeholders. Growing evidence shows the degree to which an information service

\section{FIGURE 8}

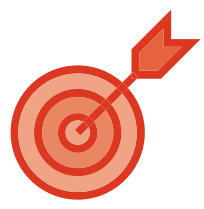

USER-CENTERED APPROACH AND IMPROVED TARGETING

Any new intervention and roll out of digital climate-in formed advisory services (DCAS) should be based on a comprehensive targeting and understanding of the users and the context in which they live to avoid entrenching existing inequity.

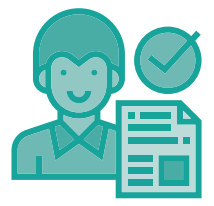

\section{BUILD THE CAPACITY FOR USERS TO EQUITABLY ENGAGE WITH DCAS}

Adequate infrastructure, digital literacy, climate literacy, awareness of opportunities, benefits and risks, access to prerequisites (e.g., radios or mobile phones), and affordable pricing will be necessary for successful DCAS. DCAS should be a complementary tool, not a stand-alone method, building on nondigital trusted relationships (e.g., with extension agents or agribusinesses) and focusing on supporting the most marginalized.

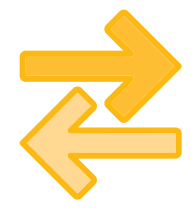

PROMOTE INTEGRATED, TWO-WAY, AND MULTICHANNEL INTERVENTIONS

DCAS need to reflect an integrated approach-relying on multiple channels and two-way communication-that complements service with measures that enhance the capacities of information producers and intermediary and last-mile users, empowering them with information for decision-making.

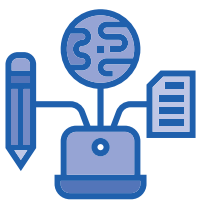

\section{EXPAND THE TYPES OF KNOWLEDGE THAT DCAS UTILIZE AND DISSEMINATE}

DCAS should move beyond classical knowledge conventions and embrace alternative scientific approaches (e.g., indigenous knowledge) and the expertise of other sectors (e.g., health, biodiversity)

When local knowledge is used, it should be remunerated or compensated (e.g., free access to services). The Technology Executive Committee under the United Nations Framework Convention on Climate Change offers recommendations for ways to develop and enhance endogenous capacities and technologies. ${ }^{a}$

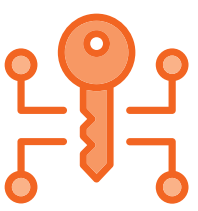

\section{ACCESS TO PRODUCTIVE ASSETS AND INPUTS}

Credit, seeds, fertilizers, and other inputs can be important preconditions for effective DCAS. Equitable access to these resources is essential for equitable DCAS outcomes.

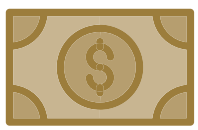

\section{INVEST IN THE “LAST MILE”}

DCAS should address last-mile challenges, including reaching offline producers and building the capacity of users. Investing in the last mile will increase the two-way flow of information and capital that many regions lack. Providing technical assistance locally and channeling impact investment to micro-, small, and medium enterprises via local intermediaries (i.e., microfinance institutions) will equip them to provide the customized products and services required for DCAS to reach the last mile. ${ }^{b}$

Notes: a. UNFCCC 2018; b. WBCSD 2021.

Source: Authors. 


\section{Box 3 | Example of the Principle of Equity in Practice}

\section{Project Title:}

- On-Demand Short Message Service for Weather, Pasture, and Market Price Information for Herders in Mongolia

\section{Aim:}

- Strengthen herders' capacity to prepare and reduce the risk of livestock losses from extreme winters, in line with the government's disaster preparedness and risk-reduction efforts

\section{Country:}

- Mongolia

\section{Dates:}

$$
\text { - 2016-20 }
$$

\section{Overview}

An on-demand short message service (SMS) helps address the information needs of livestock herders in Mongolia and supports making more informed and timely decisions about livestock movement, feeding, and shelter in preparation for and during extreme winter periods. The service was expanded nationwide in 2020. A price information feature was added to facilitate herders' hay and fodder purchases.

\section{Key features}

This service relied on digital and established nondigital means of communication, including on-demand SMS, call centers, social media, district agriculture and veterinary officers, community leaders, and students. SMS technology was considered the primary, most equitable and effective means of dissemination to herders living in remote rural areas due to weak mobile Internet coverage and limited ownership of smart or feature phones.
Service design and implementation from the outset was

- informed by the needs and preferences expressed by herders from different backgrounds based on their gender, age, location, or herd size;

- conducted incrementally and iteratively, spanning several design, implementation, review, adjustment, and expansion rounds;

- based on a participatory approach, with sufficient consultations; establishment of trust and ownership among herders, national and local governments, and service intermediaries; and

- incorporated multiple feedback channels, including faceto-face, mixed-gender interviews, call center-based user satisfaction surveys, and a free, bilingual telephone hotline to assess differences in service access and usage and distill recommendations for improvements responsive to different herder backgrounds.

\section{Lessons}

- Understand and address different user needs, preferences, capacities, and decision-making contexts through the application of user-centered design with integrated feedback mechanisms.

- Foster an enabling environment based on partnership, trust, and incremental and flexible co-creation by different actors, mindful of partners' competing priorities and existing resource allocations.

- Allocate generous time and funding horizons and integrate market-based solutions for SMS servicing during design and rollout to enable equity, broad ownership, scale, and sustainability. 
is used and valued is closely tied to users who can affect its design and have a sense of ownership. Co-created knowledge has been identified as a prerequisite for solutions that meet a farmer's context as well as build trust (Fielke et al. 2020). Co-creation processes build legitimacy by building trust, salience by aligning to farmers' real needs, and sustainability by strengthening farmers' capacities to use services and express evolving demand. However, co-creation does not necessarily mean generating a new DCAS but rather building upon existing DCAS to avoid fragmentation and redundancies. Co-creation is not so much about creating something "new" as it is about building and strengthening DCAS relationships.
Figure 9 highlights the key components of co-creation for DCAS, and Box 4 offers an example of a service that has emphasized co-creation processes.

\section{Establish Accountability and Transparency}

Accountable DCAS assures that the individuals or organizations involved can be evaluated according to their roles and responsibilities. Transparency is required for accountability because openly accessing information regarding service design, implementation, and finance is essential for understanding if services meet institutional goals and respond to user needs.

\section{FIGURE 9}

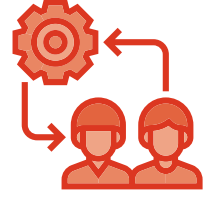

\section{BE DEMAND DRIVEN, NOT SUPPLY DRIVEN}

Outputs of the co-creation process should reflect the demand that was voiced by potential users of digital climate-informed advisory services (DCAS) rather than what is being offered by DCAS providers.

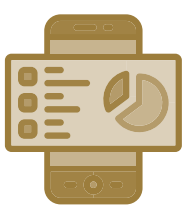

BUILD THE CAPACITY OF TARGET USERS AND SERVICE PROVIDERS SO THAT THEY CAN ACTIVELY PARTICIPATE AND ENGAGE

Not all engaged stakeholders will have the same capacities, especially with more technical climate materials. Likewise, not all climate service providers will understand the nuances of users' livelihoods, problems, systems, and needs. Therefore, two-way training may be required and/or specialized interlocutors to explain information, especially in national meteorological and hydrological services.

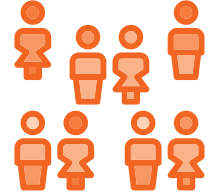

PROMOTE DIVERSITY OF ENGAGEMENT ACROSS THE DCAS VALUE CHAIN

Co-creation should emphasize the inclusion of last-mile and intermediary users from diverse backgrounds (e.g., gender, age, ethnicity, livelihood, etc.) from conceptualization to implementation.

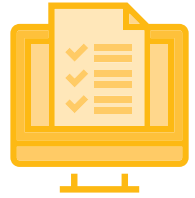

FORMALIZE AND EMBED CO-CREATION IN GOVERNANCE AND PLANNING

Co-creation must be normalized and integrated into institutional planning and implementation strategies and could be articulated through national frameworks for climate services.

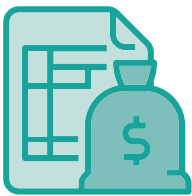

PLAN FOR AN ITERATIVE PROCESS WITH DESIGN, TIMELINES, AND BUDGETS

Co-creation will be an iterative process that will require additional time for establishing effective processes and gathering all stakeholder voices in the short, medium, and long term.

Source: Authors. 


\section{Box 4 | Example of the Principle of Co-creation in Practice}

\section{Project Title:}

- The Global Framework on Climate Services' Adaptation Programme for Africa

\section{Aim:}

- Support adaptation to climate change through improved decision-making

\section{Countries:}

- Malawi and Tanzania

\section{Dates:}

- 2013-17 (Phase I) and 2017-19 (Phase II)

\section{Overview}

The Global Framework on Climate Services' Adaptation Programme for Africa was a multipartner initiative to reduce vulnerability to climate change. A food security component, led by the World Food Programme (WFP) and the CGIAR Research Program on Climate Change, Agriculture and Food Security (CCFAS), focused on helping food-insecure communities access relevant information to manage climate variability and change. This enabled improved decision-making based upon seasonal and subseasonal weather forecasts and agricultural advice, including livestock, nutrition, and health information.

Note: See Appendix D for the list of relevant service actors.

Source: WFP authors

\section{Key features}

Co-creation was central in multiple stages of the initiative, linking the meteorological agency with the ministry of agriculture, extension services, nongovernmental organizations, and the private sector. For example, in Malawi, WFP brokered the establishment of an interministerial National Agriculture Content Development Committee where specific advice was tailored and translated to the needs and contexts of communities and informed the content of radio programs. In alignment with the Participatory Integrated Climate Services for Agriculture (PICSA) process, planning and review days were scheduled where extension officers provided farmer feedback to stakeholders, advisories based upon seasonal forecasts were coproduced, and specific focus on the role of women was prioritized. Extensive user surveys revealed that over 85 percent of users reported having more food after adopting advisory guidance, and over 75 percent reported higher income.

\section{Lessons}

- When extension agents shift their role from top-down delivery of static messages to facilitating dynamic decision-making with participatory processes, the shift greatly promotes farmer empowerment.

- Tailoring distribution channels, including nondigital, according to gender and livelihood promotes equity of information access.

- The inclusion of a feedback mechanism during the planning and review days is critical for allowing the content to evolve and adjust to changing needs. 


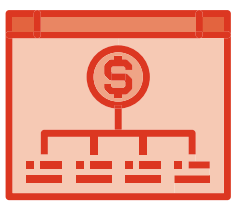

PROVIDE ADEQUATE TIMELINE AND BUDGET FOR MONITORING EVALUATION, AND LEARNING (MEL)

MEL will be essential for reporting costs, benefits, gaps, and opportunities for digital climate-informed advisory services (DCAS).

It is key for course correction, if

necessary. Documented lessons learned will also help others to avoid replication and pitfalls.

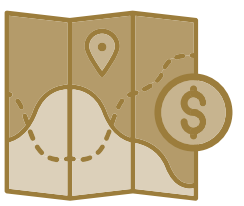

TRACK AND REPORT DCAS INVESTMENTS

Tracking and reporting of DCAS activities and finance flows will be important for building accountability and providing transparency.

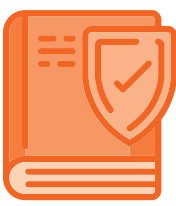

FORMALIZE OPERATIONAL GOVERNANCE MODELS

DCAS require good governance arrangements that clearly delineate institutional roles and responsibilities, including a need for institutional alliances, strong partnerships, and clear roles and responsibilities of the monitoring and evaluation of stakeholders.

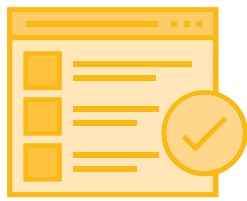

DEVELOP A STANDARD SET OF OUTCOME INDICATORS

Outcome reporting standards related to yield, income, food security (e.g., the Food Consumption Score, the Coping Strategy Index, and the Integrated Food Security Phase Classification) could help provide the necessary understanding of whether DCAS interventions are actually helping to achieve and/or maintain resilience outcomes as well as sustainable development goals. This will be important for catalyzing public and private sector investment.

\section{Box 5 | Example of the Principle of Transparency and Accountability in Practice: Digital Green}

Aim:

- Empower small-scale farmers to lift themselves out of poverty by harnessing the collective power of technology and grassroots-level partnerships

\section{Countries:}

- Predominately Ethiopia and India

\section{Dates:}

- 2009-present

\section{Overview}

Digital Green collaborates with governments, private firms, and rural communities to co-create digital solutions that are nutrition sensitive, climate resilient, and inclusive. It has developed a suite of services to fit local contexts, often combining advisory services with capacity building and training as well as other information services such as transport logistics.

\section{Key features}

In India alone, Digital Green has reached over 1.9 million smallscale farmers, 90 percent of whom are women. Digital Green's process includes continual testing, learning, iteration, and evaluation to promote resilient livelihoods and sustainable incomes. Its measured impact has been key for expansion, as local partners see results and request further scaling of the organization's innovations.

As part of Digital Green's monitoring and evaluation process, the International Food Policy Research Institute, a knowledge partner, conducted a two-year randomized control trial (RCT) in Ethiopia. The RCT compared results from Digital Green's video-enabled extension approach to the Ministry of Agriculture's conventional in-person training approach. Preliminary results show that videoenabled extension achieves 30 percent greater reach, 35 percent higher uptake of promoted practices, and a 22 percent increase in women accessing extension services.

\section{Lessons}

- Monitoring and evaluation are essential throughout project implementation for course correction and improvement of services.

- Measuring impact requires additional time and specialized partnerships.

- Evaluating equity components-such as gender-of service access and adoption is essential for reaching the last mile.

- Showing evidence of impact is key for building further demand.

Sources: Abate et al. 2019; Digital Green 2019. 
Accountability and transparency cut across all other principles. The accountability principle raises the need for governance processes and policy frameworks that support adherence to all the other principles discussed here. It also emphasizes the need for monitoring, evaluation, and iterative learning, including expanding the evidence base for DCAS by using more concrete evaluation methods (e.g., human-centered process evaluation, difference of difference, benchmarking, randomized control trials, etc.; Tall et al. 2018). Figure 10 highlights the components of accountability and transparency that are not addressed in the other principles. Furthermore, the Digital Green case study (Box 5) exemplifies how the monitoring and evaluation process was incorporated throughout the project to garner evidence of impact that leads to more engagement and improved technological solutions.

\section{Buill for Financial Sustainability}

A service is financially sustainable if it generates sufficient value to continue to operate indefinitely without donor funding, although sustained public investment is still necessary. Ultimately, private sector costs are covered by revenue and profit, and public sector costs are covered by tax revenue.

Further data and evidence is needed to show the additional commercial value of DCAS, providing customers with the real or perceived transaction costs of participation. Over the longer term, a common market analysis framework could be developed with multiple organizations contributing to help achieve an enhanced, shared understanding of the DCAS market, as highlighted recently by the Initiative for Small-scale Finance and Swiss Re. This can

\section{FIGURE 11 Key Components of Financial Sustainability for DCAS}

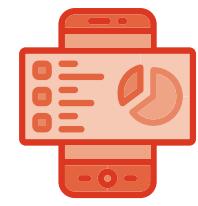

DEVELOP DIGITAL CLIMATE-INFORMED ADVISORY SERVICES (DCAS) WITH THE MAIN USER IN MIND, FOCUSING ON LAST-MILE CHALLENGES

To maintain relevance and responsiveness, DCAS should be designed to reach the broadest user segments possible while still addressing the needs of marginalized communities and be adaptive to new information needs (e.g. COVID-19, locust swarms, cyclones).

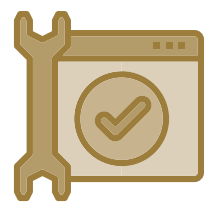

BUNDLE SERVICES AND PROMOTE EFFICIENCIES THROUGH SPECIALIZATION

Bundled services-such as DCAS complemented by insurance, market, or input services-often have higher engagement and greater benefits. In addition, promoting the delivery of specific DCAS elements through specialized segments of the value chain encourages economies of scale, reducing the overall cost of DCAS

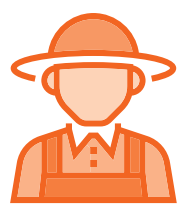

\section{FOCUS ON THE MOST RESPONSIVE} SEGMENTS

OF THE FARMING POPULATION

Establishing a foothold in responsive segments of the customer base (e.g. youth and entrepreneurial farmers) helps achieve more efficient growth in market penetration while promoting farmer-to-farmer dissemination of services.

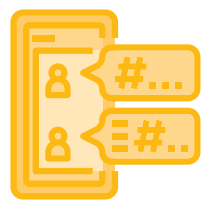

PROMOTE THE ADOPTION OF GOVERNMENT STANDARDS AND REGULATIONS IN THE DCAS SPACE

Ensuring that the market includes only well-regulated DCAS solutions that are aligned with farmers' needs will improve trust. In turn, this will improve uptake and facilitate the integration of DCAS into national/subnational plans.

Source: Authors

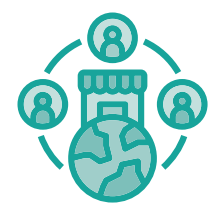

SHIFT TO AN INCLUSIVE MARKET SYSTEM APPROACH WHEN DESIGNING AND IMPLEMENTING DCAS

Rather than conceptualizing DCAS as solely a method for communicating information to farmers, the design and implementation of DCAS should consider the multiple social, economic, and environmental benefits across the value chain and throughout the market ecosystem. 


\section{Box 6 | Example of the Principle of Sustainability in Practice}

\section{Project Title:}

- Jokalante

\section{Aim:}

- Promote uptake of improved climate-smart agricultural practices to complement existing agriculture extension in a financially sustainable manner

\section{Country:}

- Senegal

\section{Dates:}

$$
\text { - 2016-present }
$$

\section{Overview}

This social enterprise uses local languages and a variety of tools to deliver credible, accessible advisory services to hard-to-reach, last-mile, farming households at scale.

\section{Key features}

Jokalante set up the TICmbay (ICT Agriculture) platform, where they collect data from farmers to enable different stakeholders to deliver a personalized service. It works with the national meteorological service to develop a financially sustainable business

Note: See Appendix D for the list of relevant service actors.

Source: Landell Mills 2019. model for sending weather advisories to farmers and fishers where interactive voice response messages and short message service (SMS) messages are sent in the recipient's preferred language.

Jokalante's revenue model is based on contracts with nongovernmental organizations, input dealers, and cooperatives, who wish to disseminate advisory services to farmers in their supply chains and projects.

\section{Lessons}

- Jokalante uses a systems approach that centers around stakeholder collaboration to map and input information into the service.

- Tailored information delivery models have allowed the project to bridge the last mile and reach 800,000 rural men and women in 12 regions of Senegal.

- Jokalante's revenue model has accelerated the expansion of service coverage. This social enterprise model has contributed to the longevity and success of the project while still allowing for a focus on serving the most vulnerable and hardest-toreach populations. better inform where to target the promotion of DCAS in agricultural systems and geographies (ISF Advisors and Swiss Re 2020).

Figure 11 highlights key considerations for building financially sustainable DCAS. Box 6 provides an example of a service that has exemplified sustainable approaches.

\section{Design for Scalle}

Scalability refers to the capacity of a climate service to be replicated, spread, or adapted to increase the level of impact (Sulaiman et al. 2018). The scalability of DCAS includes access, use, and benefit from a service; the strategies and methods employed to transition from a pilot to a subnational, national, or regional scale; and the management of the challenges and trade-offs involved in this transition. The contextual demands of farmers should determine the appropriate level of "scale" to be achieved.

Much of the appeal and strength of DCAS for building the resilience of small-scale agricultural producers comes from their potential to reach large farming populations and thus scale up beyond levels possible via other methods. Figure 12 puts forth some key elements of scalability while Box 7 provides an example of a DCAS reaching scale. 


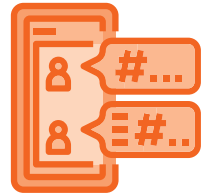

\section{PROMOTE FORWARD-LOOKING REGULATION THAT MAXIMIZES CONSISTENCY ACROSS COUNTRIES/REGIONS}

Consistent regulation would enable replication of digital climate-informed advisory services (DCAS) to countries and the development of regional service delivery. Varying regulations disincentivize scaling

DCAS because they

require customized solutions.

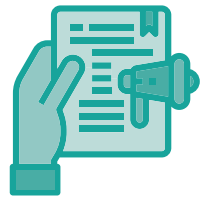

\section{SUPPORT GOVERNMENTS TO INITIATE AND MANAGE PUBLIC-PRIVATE PARTNERSHIPS (PPPS) EFFECTIVELY AND ENHANCE INTRAGOVERNMENT COORDINATION}

It is important to deepen the understanding of PPP design and management and support coordination between government ministries on DCAS. Partnerships with already existing PPP initiatives can provide further guidance and support for governments. Initiatives themselves can proactively facilitate policy change, enabling scalability.

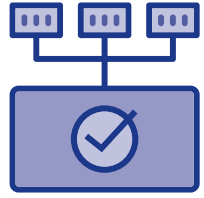

\section{INTEGRATE SERVICE PLANS INTO A} LONGER-TERM INVESTMENT PLAN

DCAS providers should formulate short-, mediumand long-term goals for DCAS. Linking planning with funding mechanisms will be critical for upscaling.

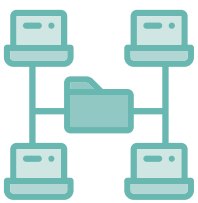

\section{MPROVE CAPACITY AND RESOURCES}

FOR COOPERATIVE DCAS SOLUTIONS and are important partners to expand the coverage of weather station infrastructure and deliver services to their members.

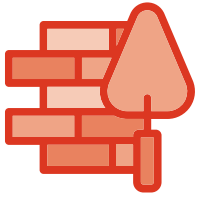

BUILD ON WHAT ALREADY EXISTS, WHEN AND WHERE POSSIBLE

Better incorporation of DCAS into existing extension services

on the national or provincial/state level is more efficient than developing parallel services. This involves technical assistance, linking government agencies to vetted DCAS providers, and covering the additional costs of adding climate components into these programs.

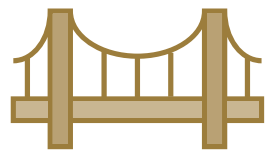

\section{BRIDGE THE ACCESS-ENGAGEMENT GAP VIA INNOVATIVE SOLUTIONS}

Engagement and application of DCAS is lagging growth rates. For digital agriculture services in Africa, only 42 percent of registered users are estimated to use the service with any frequency (Tsan et al. 2021)

Co-creation encourages engagement. Participation also can be promoted by improved DCAS timeliness and accuracy; this can be achieved, for instance, by

technological innovations including automated systems, artificial intelligence, and cloud computing.

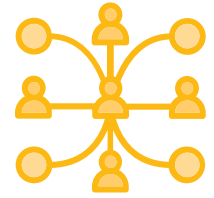

\section{ESTABLISH A COORDINATED COMMUNITY OF PRACTICE}

The DCAS community should articulate learning and innovation needs; establish areas for collective action and collaboration; and develop common tools, standards, and operational frameworks as global public goods. It is essential to understand the limits and effective interplay of development assistance,

governments, markets, and value chains.

Source: Authors

\section{SUPPORT LARGE-SCALE FARMER OUTREACH FOR PPP OR PRIVATE ENTERPRISE MODELS THAT HAVE PROVEN EFFECTIVE}

Successful delivery models that lack the resources to scale up should be identified and supported. A proposal request process could short-list projects to receive finance for scaling. 


\section{Aim:}

- Help farmers, agribusinesses, and development organizations reach rural communities with services and solutions that help improve their livelihoods

\section{Countries:}

- Over 20 countries (including Burkina Faso, Côte d'Ivoire, Ghana, and Malawi)

\section{Dates:}

- 2008-present

\section{Overview}

Esoko, a franchise model company, provides farmers with climate-informed agricultural advisories plus a range of other services, including market intelligence, a farmer helpline, and access to finance and insurance. Esoko partners with a wide range of public and private actors. Over a short period, it has reached more than 1.2 million farmers.

\section{Key features}

Esoko helps to profile people, collect field data, and deliver services that inform under-served communities in over 20 countries. With small-scale farmers as its primary focus, Esoko uses multiple data sources, including open government data, to guide farmers in improving their farming operations and securing better prices. This is achieved by improving accessibility to relevant information through automated alerts sent via short message service (SMS), voice messages, and call centers.

Financial sustainability is achieved through a farmer subscriber model and a multitiered revenue model in which data collected by Esoko (e.g., market price data) are provided to farmers and resold to business clients.

Its services can be categorized into four main areas-surveys, content, messaging, and payments-all in an integrated community management platform.

\section{Lessons}

- Combining robust technology with strong field deployment expertise is crucial for serving last-mile customers.

- Delivering a range of services, especially linking to tangible services such as digital finance, is important for sustaining farmers' willingness to pay and scaling.

- Public-private partnerships are crucial for lowering risks faced by private companies and ensuring rapid upscaling.

- Iterative interactions with small-scale farmers allow services to assess challenges, design fit-for-purpose solutions, maintain customer loyalty, and expand customer base.

\section{A Preliminary Typology for Targeting DCAS Investment}

To meet the global demand for DCAS, innovative partnership and investment models are needed. Table 3 suggests a simple typology to highlight different pathways for providing DCAS to small-scale agricultural producers. In practice, all DCAS investments and program designs should be demand driven.

Public and donor investments in infrastructure to enable DCAS are especially critical in "activate" areas. Different DCAS models will be needed within such geographies to ensure that last-mile users, and those most vulnerable, are reached with DCAS.

\section{Activate}

Countries in the "activate" category require substantial infrastructure and policy reform to create the needed enabling environment for DCAS. With limited private sector investment incentive, public and donor resources will be critical. Investment is required now so that countries can "leapfrog" into a digital future in the next decade (Cisco 2020; Steiner et al. 2020).

\section{Accelerate}

The "accelerate" categories include countries with an adequate enabling environment for digital services and private investments. For the "accelerate (low)" category, government-led farmer extension programs or donorfunded projects are more common, and they may contract with small domestic service companies (e.g., Agence Nationale de l'Aviation Civile et de la Météorologie's DCAS in Senegal) or overseas companies to assist (e.g., the Ethiopian Agricultural Transformation Agency's engagement of Digital Green). Also, large multinational agricultural companies (e.g., Yara, Syngenta Foundation) and start-ups (e.g., Hello Tractor) are still rapidly growing in these countries. 


\begin{tabular}{|c|c|c|c|c|}
\hline & \multicolumn{4}{|c|}{ DIGITAL READINESS STAGE } \\
\hline & Activate & Accelerate (low) & Accelerate (high) & Amplify \\
\hline \multirow{3}{*}{$\begin{array}{l}\text { Dominant } \\
\text { partnership } \\
\text { models }\end{array}$} & \multirow{2}{*}{$\begin{array}{l}\text { - Public- and donor-lead } \\
\text { programs }\end{array}$} & \multirow{3}{*}{$\begin{array}{l}\text { - Public-led PPPS } \\
\text { - CSO-led initiatives } \\
\text { - Public- and donor-led programs }\end{array}$} & \multirow{3}{*}{$\begin{array}{l}\text { - Private sector coopetition } \\
\text { - Private-led PPPs }\end{array}$} & \multirow{3}{*}{$\begin{array}{l}\text { - Private sector with public } \\
\text { oversight }\end{array}$} \\
\hline & & & & \\
\hline & - cSO-led initiatives & & & \\
\hline \multirow{5}{*}{$\begin{array}{l}\text { DCAS } \\
\text { investment } \\
\text { examples }\end{array}$} & - Hard and soft infrastructure & \multirow{5}{*}{$\begin{array}{l}\text { - Piloting innovative digital } \\
\text { solutions } \\
\text { - DCAS start-up investments } \\
\text { - Expansion of infrastructure }\end{array}$} & \multirow{5}{*}{$\begin{array}{l}\text { - Transboundary services } \\
\text { - Scaling digital bundled } \\
\text { services } \\
\text { - Venture capital investments } \\
\text { - Longer-term planning and } \\
\text { implementation }\end{array}$} & \multirow{5}{*}{$\begin{array}{l}\text { - High-tech digital solutions } \\
\text { - Global services } \\
\text { - DCAS for transformative } \\
\text { system shifts }\end{array}$} \\
\hline & - Focused services & & & \\
\hline & - Data policy reform & & & \\
\hline & - Budgetary reform for DCAS & & & \\
\hline & & & & \\
\hline $\begin{array}{l}\text { Example } \\
\text { countries }\end{array}$ & $\begin{array}{l}\text { - Afghanistan, Cameroon, Haiti, } \\
\text { Mozambique, Papua New } \\
\text { Guinea, Yemen }\end{array}$ & $\begin{array}{l}\text { - Bangladesh, Ecuador, Egypt, } \\
\text { Iran, Philippines, Mongolia, } \\
\text { South Africa }\end{array}$ & $\begin{array}{l}\text { - Brazil, Macedonia, Mexico, } \\
\text { Russia, Saudi Arabia, Vietnam }\end{array}$ & $\begin{array}{l}\text { - Australia, Canada, Israel, } \\
\text { Japan, Spain, United Arab } \\
\text { Emirates }\end{array}$ \\
\hline
\end{tabular}

Notes: $\mathrm{CSO}$ = civil society organization; DCAS = digital climate-informed advisory services; PPP = public-private partnership. Digital readiness stages are drawn from Cisco 2020;

a. These are services that use an integrated sector approach and consider neighboring countries' climate and natural resource use, such as FutureWater's drought monitoring tool in Vietnam (FutureWater 2014).

A more favorable private sector environment and more established companies generally operate in "accelerate (high)" countries. They may have the capacity to lead public-private partnerships (PPPs), working with government extension services to scale their coverage. Start-up and "bridge" subsidies (i.e., public and/or donor funds helping private-led DCAS) can support transitioning from public-led to private-led models.

\section{Amplify}

Countries in the "amplify" category generally have limited climate-vulnerable and under-resourced producers and thereby go beyond this blueprint's focus. Nevertheless, DCAS here are still critical for building resilience. An example is Australia, which faces increasing intensity and frequency of drought.

\section{Recommendations}

This blueprint lays out the conceptual foundation for what will be required to effectively strengthen DCAS to build the resilience of 300 million small-scale agricultural producers by 2030 . The aim was to develop a high-level conceptual foundation for promoting scaled investment that adheres to principles of good practice developed from lessons learned from many initiatives implemented to date. Coordinated global and national communities of practice need to be established to drive the additional analysis and engagement, particularly within each country, and prioritization is needed to develop an actionable and coherent investment framework to reach the desired scale (Figure 13).

In addition, to help raise the ambition and impact of DCAS, the authors recommend the following actions:

\section{- Substantially increase current investment into DCAS} by $\mathbf{2 0 3 0}$. To build the resilience of an additional 300 million small-scale agricultural producers by 2030 , the world's DCAS funders and investors will need to invest $\$ 7$ billion above business-as-usual finance. This figure is based on highly limited available evidence of what it costs to provide DCAS to smallholder producers, from setup through maintenance years. Considerable additional analysis is needed not only to refine the nature of the investment but also to better define the ROI. At a preliminary level, highly positive cost-benefit ratios and ROls (e.g., on average, 1-to-24) are expected for public and private investors, which will also drive gross domestic product growth. Producers may see average 
productivity gains of 30 percent and income gains of 25 percent, depending on the product and geography. These investments should be demand driven and target the most under-resourced and vulnerable.

\section{- Endorse and apply the six core principles for good} practice in DCAS. The key principles for good practice in DCAS (i.e., data quality and assurance, equity, co-creation, accountability and transparency, financial sustainability, and scalability) will be essential for making sure that DCAS investments are financially sustainable and optimize impact. When developing initiatives, investors should integrate these principles during conceptualization, design, and implementation; investors should provide the necessary resources and timelines to allow for their adherence. Entities for monitoring and evaluation should track indicators of their use. The DCAS community could benefit from a playbook for applying these principles, with clearly articulated guidelines and evidence of costs and benefits.

\section{- Integrate DCAS into climate risk management ap-} proaches to adaptation. Although DCAS hold great potential in supporting small-scale agricultural producers to manage increased climate variability and adapt their practices, information alone is not enough. Rather than stand-alone initiatives, DCAS should therefore be included in wider efforts, including bundled service delivery, to support climate change adaptation to maximize their potential. Moreover, they should be integrated into comprehensive risk management plans and policies, such as disaster management plans, national adaptation plans, and climate-smart agriculture investment plans.

- Invest in global public goods and a learning community of practice to accelerate the pace of change. Substantially more work is needed to further develop the DCAS investment case and, most importantly, to support national actors to develop the right frameworks and enabling conditions to welcome and leverage the needed investment. Producing global public goods and filling common knowledge gaps would address some of the barriers to scaling, including the lack of common definitions, data standards and protocols, monitoring and evaluation frameworks, and a deeper evidence base on ROIs in DCAS, especially with respect to resilience benefits. Providing these global public goods, as well as nurturing a community of practice to share knowledge and foster collaboration, would be a critical investment in reaching the desired scale and quality of service delivery.

\section{FIGURE 13 The Path forward for DCAS}

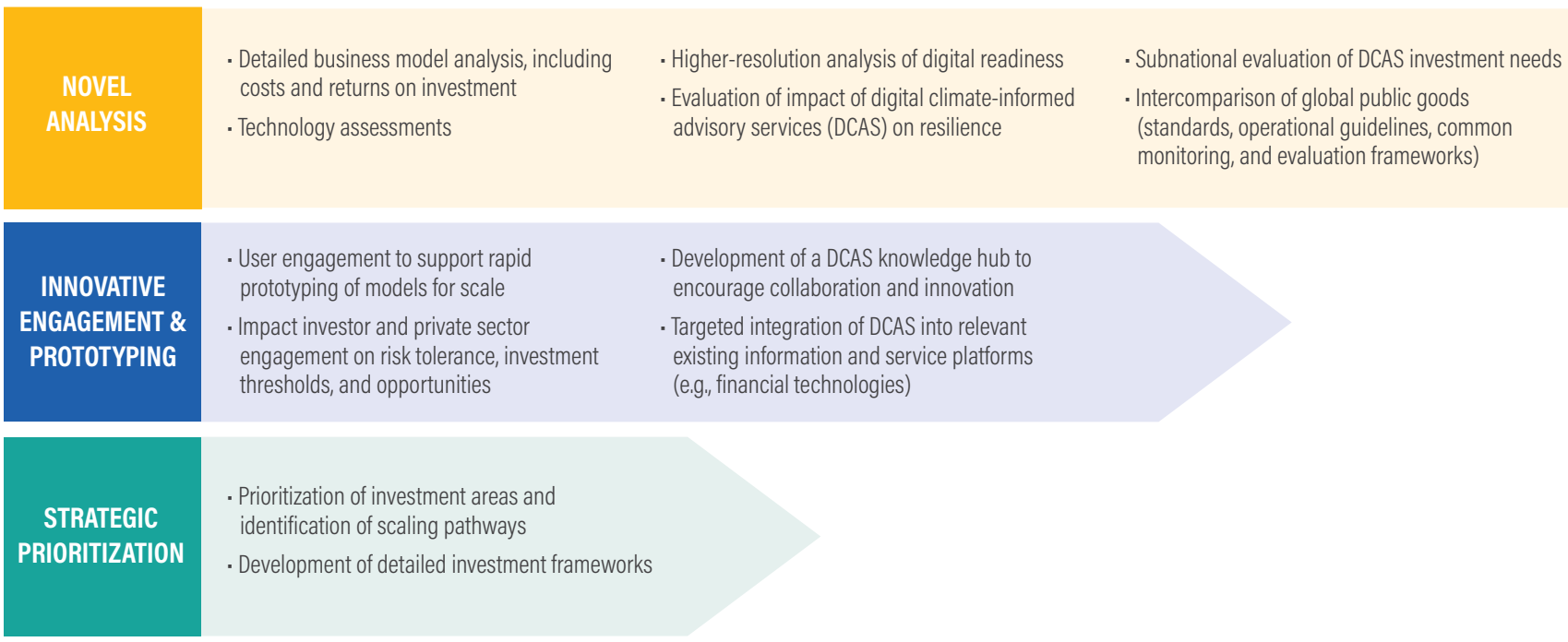

Source: Authors 


\section{Appendix A. Working Group Organizations}

Adaptation of African Agriculture Initiative Foundation (AAAI)

Agence Francaise de Development (AFD)

Agence Nationale de l'Aviation Civile et de la Météorologie, Senegal (ANACIM)

Agricultural Transformation Agency (ATA)

Alliance for a Green Revolution in Africa (AGRA)

Alliance of Bioversity International and CIAT, CGIAR

Big Data Platform, CGIAR

Blue Marble

BonRezo

Centre for Agriculture and Bioscience International (CABI)

CGIAR Research Program on Climate Change, Agriculture and Food Security (CCAFS)

Climate Corporation/Bayer

Climate Edge

Climate FarmRise/Bayer

Council for Scientific and Industrial Research, Ghana (CSIR)

CTA (Technical Center for Agricultural and Rural Cooperation, The Netherlands)

Department of Future Technologies, University of Turku

DEVCO, European Commission

DSM

Esoko

FarmERP

Global Center on Adaptation

Global Commission on Adaptation (GCA)

Global System for Mobile Communications (GSMA)

IBM

Inter-American Development Bank (IADB)
International Center for Agricultural Research in the Dry Areas (ICARDA), CGIAR

International Food Policy Research Institute (IFPRI), CGIAR

International Research Institute for Climate and Society (IRI),

Columbia University

ISF Advisors

Jomo Kenyatta University of Agriculture and Technology

Makere University

Microsoft

Netherlands Space Office

NORAD

Norwegian Refugee Council

Olam

Penelope Cabot Consulting

Practical Action

Producers Market

Public Private Partnership Europe

Regional Integrated Multi-Hazard Early Warning (RIMES)

Stockholm Environment Institute (SEI)

Syngenta Foundation for Sustainable Agriculture (SFSA)

Tetra Tech

The Bill and Melinda Gates Foundation

The Meteorological Office, United Kingdom

UN Food and Agriculture Organization (FAO)

United Nations Development Programme (UNDP)

University of Florida

University of Reading

University of Southern Queensland

World Bank Group

World Food Programme (WFP)

World Meteorological Organization (WMO)

World Resources Institute (WRI) 


\section{Appendix B. Methodologies}

This appendix provides a short description of the methodologies used in the investment blueprint. For information on included data, please contact the authors.

\section{Methodology for Global Investment Cost}

The global investment cost figures to build the resilience of 300 million small-scale producers with DCAS were calculated as stated below. These investment figures focus on the design, development, and implementation of DCAS.

1. Cost data were extracted from literature reviews and interviews.

2. Cost data were compiled and separated into two figures: start-up costs and annual maintenance costs. The specific up-front investment costs and annual maintenance costs were often not available for specific projects; instead, the overall costs for a range of years were typically provided. Multiple projects estimated their up-front costs to be between 75 percent and 80 percent of the total project costs for multiyear projects. Therefore, where no specific data was available, up-front costs were calculated by taking 75 percent of the total project costs. Annual maintenance costs were calculated by taking 25 percent of the total project costs, divided by the number of years of the project. Below Table B1 shows the costs calculated for the case studies on which data were available as well as the estimated median and mean upfront and per annum costs per producer and standard error. The projects in Table B3 cover the range of digital products DCAS generally provide, as described in Section 2. Projects include mainly bundled services, such as SMARTseeds in Indonesia and CommonSense in Ethiopia. They also include projects focusing mainly on weather forecasts and agricultural practice advice, such as Global Based Information Services for Small-Scale Farmers (GEOBIS) in Bangladesh.

3. Annual maintenance costs were kept as equal between years as marginal costs tend to be low, rapidly approaching zero with added users. These annual maintenance costs assume a base cost for maintaining infrastructure.

4. Project costs were calculated as cost per smallscale producer.

5. Mean, median, and standard error were calculated. These figures are shown in Table B2.

6. The mean value was used to provide one overall figure for the investment needs. For the up-front investment costs, the mean value was $\$ 16.20$ per small-scale producer. For the annual investment costs, the mean value was $\$ 1.75$ per producer.

TABLE B1 $\quad$ The Path forward for DCAS

\begin{tabular}{|c|c|c|c|c|c|}
\hline PROJECT OR PROGRAM & COUNTRIES & $\begin{array}{l}\text { DIGITAL } \\
\text { READINESS }\end{array}$ & $\begin{array}{l}\text { NUMBER OF } \\
\text { PRODUCERS } \\
\text { REACHED }\end{array}$ & $\begin{array}{l}\text { ESTIMATED } \\
\text { UP-FRONT PER } \\
\text { PRODUCER COST } \\
\text { (US\$) }\end{array}$ & $\begin{array}{l}\text { ESTIMATED ANNUALLY } \\
\text { RECURRENT PER PRODUCER } \\
\text { COST (US\$) }\end{array}$ \\
\hline aWhere ${ }^{b}$ & Kenya & Accelerate (low) & 15,000 & 3.80 & 1.00 \\
\hline CommonSense $^{c}$ & Ethiopia & Activate & 387,300 & 10.45 & 0.87 \\
\hline Esoko $^{d}$ & Ghana & Accelerate (low) & & 4.43 (average) & $\mathrm{N} / \mathrm{A}$ \\
\hline GEODATICS & $\begin{array}{l}\text { Kenya, } \\
\text { Tanzania }\end{array}$ & $\begin{array}{l}\text { Accelerate } \\
\text { (low), } \\
\text { Accelerate (low) }\end{array}$ & 67,500 & 31.50 & 3.00 \\
\hline $\begin{array}{l}\text { Global Based Information } \\
\text { Services for Small-Scale } \\
\text { Farmers (GEOBIS) }\end{array}$ & Bangladesh & Accelerate (low) & $1,521,346$ & 1.60 & 0.18 \\
\hline
\end{tabular}

$\begin{array}{lllll}\begin{array}{l}\text { GREENCoffee Mobile } \\ \text { Services Application }\end{array} & \text { Vietnam } & \begin{array}{l}\text { Accelerate } \\ \text { (high) }\end{array} & 119,573 & 25.60\end{array}$

\begin{tabular}{|c|}
\hline $\begin{array}{l}\text { Intelligent Decision } \\
\text { Support Systems (IDSS) }\end{array}$ \\
\hline
\end{tabular}



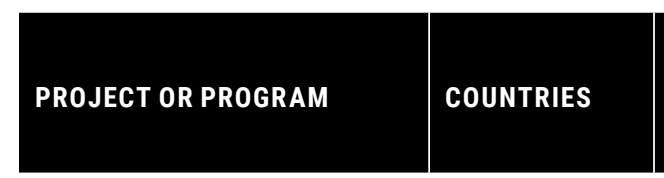

Market-led, Userowned ICT4Ag-enabled Information Service (MUIIS)

\section{DIGITAL \\ READINESS \\ NUMBER OF \\ PRODUCERS REACHED \\ ESTIMATED \\ UP-FRONT PER \\ PRODUCER COST (US\$)}

Uganda Activate

$5,723,813$

0.70
ESTIMATED ANNUALLY RECURRENT PER PRODUCER COST (US\$)

\section{Mobile Data for Moving \\ Herd Management and Better Incomes (MODHEM)}

Burkina Faso Activate

0.01

\section{Myanmar Mobile Value-Added Services for Agriculture \\ (MYVAS4AGRI) $^{\mathrm{k}}$}

\begin{tabular}{llllll|}
$\begin{array}{l}\text { Precision Agriculture for } \\
\text { Development (PAD)' }\end{array}$ & India & Accelerate (low) & 1,200 & 15.00 & 2.50 \\
\hline $\begin{array}{l}\text { Proposed Climate-Smart } \\
\text { Agriculture Investment } \\
\text { Plan' }\end{array}$ & Cote d'Ivoire & Accelerate (low) & 312,500 & 49.50 & 3.30 \\
\hline $\begin{array}{l}\text { Satellite Data for Rice } \\
\text { Farmers/Production } \\
\text { (Sat4Rice) }\end{array}$ & Vietnam & $\begin{array}{l}\text { Accelerate } \\
\text { (high) }\end{array}$ & 152,064 & 13.10 & 1.45 \\
\hline SMARTseeds & Indonesia & Accelerate (low) & 572,968 & 0.51 \\
\hline $\begin{array}{l}\text { Rwanda Climate Services } \\
\text { for Agriculture Project }\end{array}$ & Rwanda & Accelerate (low) & & 4.60 & 1.45 \\
\hline MEDIAN & & & 2.50 & 1.75 \\
\hline MEAN & & & 10.45 & 0.36 \\
\hline Standard error & & & 16.20 & .01 \\
\hline Minimum & & & 4.43 & 4.60 \\
\hline Maximum & & & 0.70 & 54.8 \\
\hline
\end{tabular}

Notes: The estimated up-front costs are 75 percent of total project costs. In reality, these costs will differ vastly according to context.

a. Definitions of digital readiness categories: Cisco scores countries on a scale of 1-25, based off a holistic set of indicators that go beyond technology to include basic needs, human capital development, and business/start-up environment. The designations amplify, accelerate, and activate reflect how closely a country score compares to the 2019 average score of 11.90 :

- Activate countries are in the earliest steps of their digital journey; average score of 6.24

- Accelerate countries have taken some steps forward but have significant opportunities to accelerate or improve in their digital readiness; due to volume of countries in this stage, countries

are categorized as "accelerate (high)" if their score is above the group mean of 11.82 or "accelerate (low)" if their score is below the mean.

- Amplify countries have made significant strides in developing various components of their economy that support digital maturity; average score of 17.89.

b. aWhere 2020; c. G4AW n.d.a.; d. Esoko 2020; e. G4AW n.d.c.; ;. G4AW n.d.b.; g. Avko Foundation n.d.; h. G4AW n.d.d.; i. G4AW n.d.f.j G4AW n.d.e.; k. G4AW n.d.g.; Cole and Fernando 2016; m. WBG 2019; n. G4AW n.d.h.; o. G4AW n.d.i.; p. Nsengiyumva et al. 2018.

Source: Authors. 
7. However, because of limited available data, the up-front global investment costs needed to reach 300 million producers by 2030 are also presented as a range-the 95 percent confidence limits of the mean-as follows:

a. Global up-front investment needs to reach 300 million producers with a confidence of 95 percent:

i. Lower limit = (mean of estimated up-front per producer cost - (standard error $\times 2)) \times 300$ million producers $=\$ 2.2$ billion

ii. Upper limit = (mean of estimated up-front per producer cost + (standard error $\times 2)) \times 300$ million producers $=\$ 7.5$ billion

8. The overall investment figure needed-up-front and recurrent costs-was calculated by assuming a growth trend in smallscale producers supported by DCAS for 2021-30, based upon historical growth trends. Whereas some of the 300 million producers will be reached soon, for others it will be closer to 2030; thus, recurrent costs increase over time as more producers are reached. Historic growth trends were based upon the Digitalisation of African Agriculture Report, 2018-2019, by the Technical Centre for Agricultural and Rural Cooperation (CTA), which analyzed annual growth trends
(Tsan et al. 2021). By using the CTA's current numbers of unique digitalization for agriculture (D4Ag) users and the GSMA's data on the share of DCAS in D4Ag, baseline values of DCAS users over the period 2016-19 were calculated, and that trend line was extended to 2030, with the final target of 300 million additional users by 2030. Thus, the number of additional users could be calculated for each year as well as the total maintenance costs per year.

9. For the annual cost per small-scale producer, the lower and upper limits of the 95 percent confidence interval were used as well as the mean value. The calculations led to an estimated mean of $\$ 1.8$ billion needed on annual costs to support producers throughout 2021-30 with DCAS. Table B2 presents the lower and upper limits for the 95 percent confidence interval. Together with the mean up-front cost of $\$ 4.9$ billion (\$16.20 x 300 million small-scale producers), the mean total cost for supporting 300 million additional smallscale producers with DCAS was estimated to be $\$ 6.6$ billion.

10. The low-end and high-end total costs for the 95 percent confidence interval were also calculated and are shown in Table B2. Given the limited data, we use \$7 billion as the order of magnitude of investment funds needed to ensure that 300 million producers are serviced by DCAS.

\begin{tabular}{|c|c|c|c|}
\hline & \multirow{2}{*}{$\begin{array}{l}\text { TOTAL UP-FRONT } \\
\text { COSTS (USS, } \\
\text { BILLIONS) }\end{array}$} & $\begin{array}{l}\text { TOTAL ANNUAL RECURRENT COSTS (USS, } \\
\text { BILLIONS) }\end{array}$ & TOTAL COSTS (USS, BILLIONS) \\
\hline & & aWhere $^{a}$ & $\begin{array}{l}\text { Market-led, User-owned ICT4Ag-enabled } \\
\text { Information Services (MUIIS) }\end{array}$ \\
\hline $\begin{array}{l}\text { Lower Limit } \\
\text { ( } 95 \% \text { confidence) }\end{array}$ & 2.2 & 1.0 & 3.22 \\
\hline Mean & 4.9 & 1.8 & 6.7 \\
\hline $\begin{array}{l}\text { Upper Limit } \\
\text { ( } 95 \% \text { confidence) }\end{array}$ & 7.5 & 22.5 & $1,010.0$ \\
\hline
\end{tabular}

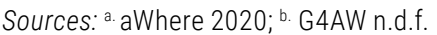




\section{Additional Data on Small-Scale Producer Productivity and Income Gains due to DCAS}

TABLE B3 Identified Productivity and Income Gains for Small-Scale Producers due to DCAS Use

\begin{tabular}{|c|c|c|c|}
\hline PROJECT OR PROGRAM & COUNTRY & $\begin{array}{l}\text { PRODUCTIVITY GAINS } \\
(\%)\end{array}$ & INCOME GAINS (\%) \\
\hline $\begin{array}{l}\text { Participatory Integrated Climate Services for Agriculture } \\
\text { (PICSA) }^{a}\end{array}$ & Rwanda & 24 & 30 \\
\hline DigiFarm (Safaricom) Decision Agriculture \& Weather ${ }^{b}$ & Kenya & 70 & 70 \\
\hline GEODATICSc & Tanzania & 23.3 & $\mathrm{n} / \mathrm{a}$ \\
\hline GEODATICS ${ }^{d}$ & Kenya & 82.3 & $\mathrm{n} / \mathrm{a}$ \\
\hline IDSSe & Bangladesh & $\mathrm{n} / \mathrm{a}$ & 19.5 \\
\hline GEOBIS ${ }^{f}$ & Bangladesh & 7 & 12.5 \\
\hline DigiFarm (Safaricom) Market Linkages ${ }^{g}$ & Kenya & $\mathrm{n} / \mathrm{a}$ & 100 \\
\hline Precision Agriculture for Development ${ }^{\mathrm{h}}$ & India & 28 (cumin), 8.6 (cotton) & $\mathrm{n} / \mathrm{a}$ \\
\hline GEOBISi & India & 30 & $\mathrm{n} / \mathrm{a}$ \\
\hline MUISS & Uganda & 67 & 70 \\
\hline $\begin{array}{l}\text { Myanmar Mobile Value-Added Services for Agriculture } \\
(\text { MYVAS4AGRI)k }\end{array}$ & Myanmar & $n / a$ & 10 \\
\hline PICSA and radio listening clubs ${ }^{\prime}$ & Rwanda & 47 & 56 \\
\hline Esokom & Ghana & $\mathrm{n} / \mathrm{a}$ & $\begin{array}{l}10 \text { (maize), } 7 \\
\text { (groundnut) }\end{array}$ \\
\hline
\end{tabular}

Note: $\mathrm{n} / \mathrm{a}=$ not applicable.

Sources: a. University of Reading n.d; b. Safaricom 2020; c. G4AW n.d.c.; d. G4AW n.d.c.; e. G4AW n.d.d.; f. G4AW n.d.b.; g. Safaricom 2020; h. Cole and Fernando 2016; i. G4AW n.d.b.; Microsoft News Center 2017; ' k. G4AW n.d.g.; ' University of Reading n.d.; m. van Schalkwyk et al. 2017. 


\section{Additional Data on Efficiency Gains Measured in Input Reductions due to DCAS}

TABLE B4 Input Use Reductions due to the Introduction of DCAS in Example Projects

\begin{tabular}{|c|c|c|c|c|}
\hline PROJECT & $\begin{array}{l}\text { SEEDS } \\
(\%)\end{array}$ & $\begin{array}{l}\text { FERTILIZERS } \\
(\%)\end{array}$ & $\begin{array}{l}\text { WATER } \\
(\%)\end{array}$ & $\begin{array}{l}\text { PESTICIDES } \\
(\%)\end{array}$ \\
\hline $\begin{array}{l}\text { Geodata Based Information Services for Small-Scale Farmers (GEOBIS), } \\
\text { Bangladesha }\end{array}$ & 5.0 & 2.0 & $\mathrm{n} / \mathrm{a}$ & 5.0 \\
\hline Intelligent Decision Support System (IDSS), Bangladesh ${ }^{b}$ & 30.0 & 20.0 & 15.0 & 20.0 \\
\hline Mobile Data for Moving Herd Management (MODHEM), Burkina Faso ${ }^{c}$ & 9.9 & 17.1 & $\mathrm{n} / \mathrm{a}$ & 11.4 \\
\hline $\begin{array}{l}\text { Myanmar Mobile Value-Added Services for Agriculture (MYVAS4AGRI), } \\
\text { Myanmar }{ }^{d}\end{array}$ & 2.0 & 2.0 & 2.0 & 2.0 \\
\hline
\end{tabular}

Note: $\mathrm{n} / \mathrm{a}=$ not applicable

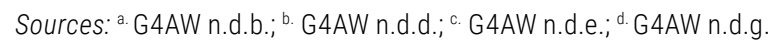

\section{Methodology and Background Information on ROIs and Cost-Benefit Ratios}

Table B5 presents examples of cost-benefit ratios and ROls for DCAS. These were obtained either directly from available sources or indirectly via calculations. The listed cases are just examples of available data.

\section{TABLE B5 Examples of Cost-Benefit Ratios and ROIs for DCAS}

\begin{tabular}{|l|l|l|l|}
\hline PROJECT OR PROGRAM & COUNTRY & DATA POINT (US\$) & SOURCE \\
\hline $\begin{array}{l}\text { Satellite-Assisted Pastoral } \\
\begin{array}{l}\text { Resource Management } \\
\text { (SAPARM) }\end{array}\end{array}$ & Ethiopia & Cost-benefit ratio of 1:48 & USAID 2015 \\
\hline $\begin{array}{l}\text { aWhere } \\
\text { Kenya }\end{array}$ & India & $\begin{array}{l}\text { Up to 1:14 cost-benefit ratio } \\
\text { per year }\end{array}$ & aWhere 2020 \\
$\begin{array}{l}\text { Precision Agriculture } \\
\text { for Development }\end{array}$ & Cost-benefit ratio of 1:10 & Cole and Fernando 2016 \\
\hline
\end{tabular}




\section{Methodology for Digital Readiness and Food System Vulnerability Map}

To develop the Digital Readiness and Food System Vulnerability Map, the following steps were taken:

1. Data on digital readiness and food system vulnerability were compiled from Cisco (2020) and ND-GAIN (2020).

2. High-income countries were eliminated from the compiled data, according to World Bank (2020) categories.

3. A three-by-three matrix for digital readiness and vulnerability was created with three tiers, according to the

a. minimum value to the midpoint of the minimum and median values;

b. midpoint of the minimum and median to midpoint of the median and maximum values; and

c. midpoint of the median and maximum to the maximum values.

4. Each tier was assigned a different proxy value integer.

5. Proxy values for each axis (digital readiness and vulnerability) were added together to find placement on the threeby-three matrix.

6. The data was mapped using Flourish mapping software.

The Cisco Global Digital Readiness Index (Cisco 2020) includes the following factors in its analysis:

- Basic needs (e.g., life expectancy, access to electricity)

- Business and government investment (e.g., research and development expenditures, investment freedom)

- Ease of doing business (e.g., rule of law, time to get electricity)

- Human capital (e.g., literacy rate, labor force participation)

- Start-up environment (e.g., new business density, venture capital investments)
- Technology adoption (e.g., mobile cellular penetration, Internet usage)

- Technology infrastructure (e.g., mobile broadband subscriptions, secure Internet servers)

The ND-GAIN Food System Vulnerability Indicator includes the following factors in its analysis:

- Projected change in agricultural cereal yield

- Projected population change

- Food import dependency

- Rural population

- Agriculture capacity (i.e., capacity to equip agriculture areas with irrigation, total fertilizer use on arable and permanent crop area use, pesticide use, and tractor use)

- Child malnutrition 


\section{Methodology for Global Finance Flows}

The following steps were taken to develop the global finance flows overview:

1. The parameters used for data collection stated that the investment must be targeted at

a. advisory services;

b. climate change;

c. either DCAS relevant infrastructure, service development, service implementation, or DCAS-specific research; and

d. only projects that were completed during or after 2015 were included. This includes projects that are still ongoing, with the latest project expected to be completed in 2027.

2. Raw data was collected via organization focal point interviews and/or analyses of organization portfolio documents.

3. In the case that information was collected from openly available documents and DCAS was only a portion of the project or program, only that portion was included in the data set. Administration and execution costs of that project or program were also included as an equivalent percentage of the DCAS component to the total project cost.

4. Global and continental projects or programs were separated out from the rest of the data.

5. If project or program data was a net sum for multiple countries, it was assumed that each country received an equal share of investment.

6. For data that was provided in currencies other than U.S. dollars, these were converted to U.S. dollars based on the average conversion rate during the initial year of the project or program.

7. Investment values were adjusted for inflation so that values were equivalent to the value of U.S. dollars in October 2020.

It should be noted that the amount of investment that has been used to generate or improve DCAS is difficult to estimate for several reasons:

- Investors, especially the public and donor sectors, often do not track expenditures for DCAS.
- DCAS investments are often just one part of a larger suite of project activities, and specific expenditures for this component are not delineated.

- In PPPs, not all involved partners have a streamlined expenditurereporting mechanism; therefore, there is a risk of double or undercounting.

- Investments in DCAS in one region may be able to "buy" more than in other regions due to purchasing power parity. However, many DCAS projects in low-income countries are often administrated or implemented by actors in high-income countries, which skews purchasing power parity. Additionally, DCAS projects or programs that involve investment in infrastructure may purchase materials or technology from nondomestic sources.

Data were collected from the following organizations and programs:

- Adaptation Fund

- African Development Bank (AfDB)

- Agence Française de Développement (AFD)

- Bill \& Melinda Gates Foundation (BMGF)

- Department for International Development (DFID), United Kingdom (now known as the Foreign, Commonwealth \& Development Office)

- Deutsche Gesellschaft für Internationale Zusammenarbeit (GIZ)

- Dutch Ministry for Foreign Affairs (DMFA)

- Geodata for Agriculture and Water (GAAW)

- Green Climate Fund (GCF)

- Least Developed Countries Fund (LDCF)

- Mastercard Foundation (MCF)

- Norwegian Agency for Development Cooperation (Norad)

- Pilot Program for Climate Resilience (PPCR)

- Swiss Development Cooperation (SDC)

- United Kingdom Agency for International Development (UKAID)

- United States Agency for International Development (USAID)

- World Bank Group (WBG) 


\section{Appendix C: Additional Resources for Data Quality Standards}

The following resources (Table C1) are examples of existing standards and guidelines relevant for DCAS. As previously noted, the principles outlined in this paper elaborate on the Principles for Digital Development. However, these other resources have additional depth to components of data conduct, management, and operational practices.

\section{TABLE C1 Key Data Quality Standards and Governance Principles}

\begin{tabular}{|c|c|c|c|}
\hline STANDARD & AUTHORITY & APPLIES TO & REFERENCE \\
\hline Principles for Digital Development & $\mathrm{n} / \mathrm{a}$ & $\begin{array}{l}\text { Digital technologies for cross-sectoral } \\
\text { development }\end{array}$ & $\begin{array}{l}\text { https://digitalprinciples. } \\
\text { org }\end{array}$ \\
\hline Open Data Charter & $n / a$ & Governance principles for public data & $\begin{array}{l}\text { https://opendatacharter. } \\
\text { net }\end{array}$ \\
\hline Open Up Guide for Agriculture & $\begin{array}{l}\text { Open Data Charter and Global } \\
\text { Open Data for Agriculture and } \\
\text { Nutrition (GODAN) }\end{array}$ & Governance for public agricultural data & $\begin{array}{l}\text { https://openupguideforag. } \\
\text { info }\end{array}$ \\
\hline Code of Conduct Toolkit & GODAN & Use and governance of farmers' private data & $\begin{array}{l}\text { https://www.godan.info/ } \\
\text { codes }\end{array}$ \\
\hline Responsible Data Guidelines & $\begin{array}{l}\text { CGIAR Platform for Big Data } \\
\text { in Agriculture }\end{array}$ & Use and governance of farmers' private data & $\begin{array}{l}\text { https://bigdata.cgiar. } \\
\text { org/responsible-data- } \\
\text { guidelines/ }\end{array}$ \\
\hline ICASA Version 2.0 data standards & $\begin{array}{l}\text { International Consortium } \\
\text { for Agricultural Systems } \\
\text { Applications (ICASA) }\end{array}$ & Crop modeling data & White et al. 2013 \\
\hline $\begin{array}{l}\text { Climate Data Management System } \\
\text { Specifications }\end{array}$ & $\begin{array}{l}\text { World Meteorological } \\
\text { Organization (WMO) }\end{array}$ & $\begin{array}{l}\text { Management and governance of climate } \\
\text { data }\end{array}$ & WMO 2014a \\
\hline $\begin{array}{l}\text { Guidance on Operational Practices for } \\
\text { Objective Seasonal Forecasting }\end{array}$ & WMO & Seasonal forecasting & WMO 2020 \\
\hline $\begin{array}{l}\text { FAIR Guiding Principles for Scientific } \\
\text { Data Management and Stewardship }\end{array}$ & WMO & $\begin{array}{l}\text { Four principles (findability, accessibility, } \\
\text { interoperability, reusability) for research data } \\
\text { and publications }\end{array}$ & Wilkinson et al. 2016 \\
\hline
\end{tabular}

Guidelines on Quality Management for WMO Climate Services (Report 1221)
This guideline applies Standard 9001 of the International Organization for Standardization on quality management standards for climate services
WMO 2018
Food and Agriculture Organization of the United Nations (FAO)
Open Data Licensing for Statistical Databases
WMO

Guide to Agricultural Meteorological Practices

(Report 134)
FAO 2020a

Open data licensing

FAO 2020a

Note: $\mathrm{n} / \mathrm{a}=$ not applicable 


\section{Appendix D: Examples of Cost Categories for DCAS}

\section{TABLE D1 Examples of Cost Categories for DCAS}

COST CATEGORY

Infrastructure

\section{EXAMPLE}

National meteorological and hydrological services (NMHS)

Initiatives such as the Systematic Observations Financing Facility, spearheaded by the World Meteorological Organization, will support 68 countries, primarily least developed countries and small island developing states, to expand their observation networks to generate and exchange basic observational weather data from the NMHS. It estimates that US\$400 million would be required over 5 years to bring all 68 countries into compliance with the Global Basic Observing Network, established at the 2019 World Meteorological Congress. The World Bank estimates such investments could yield a 1:26 return on investment. ${ }^{a}$

Telecommunications

The Global System for Mobile Communications (GSMA) estimates that in Sub-Saharan Africa, mobile operators will invest $\$ 52$ billion in infrastructure rollouts between 2019 and 2025 despite economic uncertainty due to the COVID-19 crisis. This is predicted to yield half a billion mobile subscribers in SubSaharan Africa by 2021, 1 billion mobile connections by 2024, and $50 \%$ subscriber penetration by 2025. ${ }^{b}$ However, taxes on mobile ownership constitute $7 \%$ of income for the bottom $20 \%$ earners-well above the $2 \%$ affordability target set by the United Nations, limiting mobile penetration and incentive for private investment in mobile infrastructure. ${ }^{c}$

\section{Enabling environment}

Government leadership

The Food and Agriculture Organization of the United Nations has recently proposed the establishment of an International Digital Council for Food and Agriculture that will advise governments and other relevant actors and drive the exchange of ideas and experiences to harness the opportunities presented by digitalization. ${ }^{d}$ This was developed in response to a request from 74 agriculture ministers and high-level representatives from international organizations during the 2019 Global Forum for Food and Agriculture. A national framework for climate services (NFCS), as outlined by the Global Framework for Climate Services office, will also improve coordination and leadership among domestic actors using digital climate-informed advisory services (DCAS). NFCS progress is evident across Sub-Saharan Africa and western South America but is largely lacking in much of the rest of the world. ${ }^{e}$

Standards, protocols, and regulations

Human-centered co-creation processes

Partnership development
See Appendix C.

The Participatory Integrated Climate Services for Agriculture (PICSA) is a participatory approach for climate services and agricultural extension, now in use in 20 countries. ${ }^{f}$ PICSA combines historical climate data and forecasts with farmers' knowledge of what works in their own context. It then uses participatory planning methods to help them make informed decisions about their agricultural practice. ${ }^{9}$

As an example, Mercy Corps' AgriFin program provides market facilitation to drive collaboration and innovation between financial institutions, mobile networks, educators, climate information providers, tech start-ups, and government to develop and deliver DCAS and other digital solutions for smallholder farmers. ${ }^{h}$ It conducts farmer-centric and farmer-driven market research and needs assessments, identifies core delivery partners and additional bundled service providers, and links service delivery to farmer education and digital literacy campaigns, acting as a trusted broker and intermediary to develop scalable solutions. 
Institutional readiness

The Climate for Development in Africa Programme is an initiative of the African Union Commission, the United Nations Economic Commission for Africa, and the African Development Bank that aims to enhance the capacity of national and regional institutions to produce, disseminate, and use high-quality climate information for development decision-making. Similarly, the Global Forum for Rural Advisory Services helps to enhance the performance of advisory services by focusing on the efficacy and professionalism of institutional networks that offer rural advisory services. ${ }^{j}$

\section{Development and startup costs}

Technology development and maintenance
Both private sector or proprietary platforms and open-source systems entail their own set of costs, especially related to installation and maintenance. There are trade-offs between subscribing to a prebuilt, robust private platform versus creating and maintaining open-source software. Private platforms may have the advantage of not being beholden to inconsistent donor or public funding for maintenance. Opensource software may reduce transactions costs through interoperability and transparent methodologies while also offering greater flexibility in the longer term by not being locked in to expensive vendor contracts.

The Digital Public Goods Alliance is an initiative that facilitates the identification, development, use of, registration of, and investment in digital public goods as a method of reducing investment redundancies. ${ }^{k}$ For example, FarmStack is an open-source, interoperable, standardized data platform helping organizations and farmers integrate data to generate customized information for farmers, which can be disseminated over a variety of mechanisms.

Enumeration and registration of farmers

Enumeration (i.e., identifying and counting) and registration of farmers can be one of the largest cost categories for DCAS. Costs can be reduced by leveraging existing public sector programs that enumerate farmers, such as social safety net programs, or private sector efforts that enumerate farmers as part of value chain traceability, agribusiness, or telecom loyalty programs. Additional enumeration can also be avoided by simply bundling with existing services.

The central government in India is creating a nationwide digital farmer database, linking an individual's biometric identification number (aadhar) to deliver farm-oriented benefit schemes.'

Validation of simulation models

Validation of models can be costly. Validation could be done as a global public good to reduce the costs for DCAS providers and increase the robustness of models. For example, the Agricultural Model Intercomparison and Improvement Project (AgMIP) conducts global and regional assessments, crop model intercomparisons, and produces open-source data and visualization tools as a global public good to foster innovations, such as DCAS. ${ }^{\text {m }}$

As the environment continually changes and climate variability increases, these types of models will need to be updated and validated more frequently. This can be supported by automated data collection systems (e.g., climate and hydrology) as well as by leveraging big data in smart farming by using sensors as part of the Internet of Things and cloud computing. ${ }^{n}$

Monitoring and evaluation of DCAS inputs and outputs

Although simulation models are useful for understanding general conditions and trends and informing policies and plans, advisories should be based on agricultural knowledge and evidence (e.g., field trials, lab testing, user experience, etc.). It is not just agroclimatic simulation models that require validation; agricultural research inputs that inform DCAS also require thorough monitoring and evaluation before being integrated into DCAS design. On the other side, application of DCAS recommendations or information should be critically monitored and evaluated to inform improved iterations of DCAS models. Digital Green provides an example of how to evaluate impacts through randomized control trials. ${ }^{\circ}$

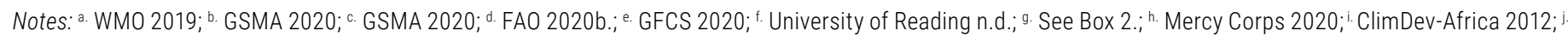
GFRAS 2021; k. Digital Public Goods Alliance n.d.;.'. Chhabra 2020; m. AgMIP 2020; n. Wolfert et al. 2017; o. See Box 5.

Source: Authors 


\section{Appendix E: List of Case Study- Relevant Actors}

\section{Box 2: Rwanda Climate Services for Agriculture}

- CCAFS-lead partner

- CIAT

- NMHS

- Meteo Rwanda

- Rwanda Agricultural Board

- $|\mathrm{R}|$

- University of Reading

- World Agroforestry Centre

- USAID-funder

Box 3: SMS On-Demand Service for Weather, Pasture, and Market Price Information for Herders in Mongolia

- Mercy Corps-project convener, platform developer, and provider of technical, financial, and staffing support

- Mongolia National Emergency Management Agency-platform manager and project implementer

- WFP-project implementer

- National Agency for Meteorology and Environmental Monitoring-access provider to official weather forecasts and pasture information

- Mongolia's National Statistics Office-access provider to official hay and fodder price statistics

- USAID's Bureau for Humanitarian Assistance and the European Civil Protection and Humanitarian Aid Operations-multiyear donor funding

- Communications Information and Technology Authority, G-Mobile, Mobicom, Skytel, and Unitel-access providers to special number and mobile network at not-for-profit rates for short message service (SMS)

- Local government authorities-service intermediaries that primarily conduct trainings, raise awareness, and engage users

- Herders-last-mile users

- People in Need-implementation partners for weather information expansion

- WFP-technical assistance provider and cofunder for the market price information expansion
Box 4: The Global Framework on Climate Services' Adaptation Programme for Africa

- WM0-lead implementing partner

- CCAFS-research partners for Phase I

- Chr. Michelsen Institute-research partner for Phase I

- International Federation of Red Cross and Red Crescent Societiesimplementing partner

- WFP-implementing partner

- World Health Organization-implementing partner

- CCAFS and WFP-food security component leaders

- Malawi Department of Climate Change and Meteorological Services and the Tanzania Meteorological Agency-national implementing partners

- University of Reading-implementing partner

- Farm Radio International and Farm Radio Africa-implementing partners

Box 6: Jokalante

- United Purpose-consortium lead of TICmbay

- Practical Action-consortium member

- SBC4D-consortium member

Box 7: Esoko

- Esoko-provides digital platform, field deployment, and helpline

- Ministries of Food and Agriculture-content for extension messages

- Meteorological Agency-provides seasonal weather data and training; served as technical backstop for Esoko farmer helpline

- aWhere-provides virtual weather stations for observed, forecast, and crop and disease model information

- Telecoms (e.g., Vodafone, MTN)-SMS gateway and mobile money payment services

- MicroEnsure-insurance provider

- Expert network from research- and agriculture-based institutions (e.g., CGIAR)-reviews all o Esoko content and provides trainings on new/updated agricultural protocols; conducts research on farmers and messaging

- World Bank/donors-fund some of the start-up costs 


\section{Abbreviations}

AFD

AfDB

AgMIP

AGRA

ANACIM

APA

ATA

BMGF

CABI

CCAFS

CIAT

CSIR

DCAS

DFID

D4Ag

DMFA

ENACTS

FAO

GCA

GCF

GEOBIS

GFCS

G4AW

GIZ

GSMA

ICARDA

IDB
Agence Française de Développement

African Development Bank

Agricultural Model Intercomparison and Improvement Project

Alliance for a Green Revolution in Africa

Agence Nationale de l'Aviation Civile et de la Météorologie, Senegal

Adaptation Programme for Africa

Agricultural Transformation Agency

Bill \& Melinda Gates Foundation

Centre for Agriculture and Bioscience International

CGIAR Research Program on Climate Change, Agriculture and Food Security

International Center for Tropical Agriculture

Council for Scientific and Industrial Research

digital climate-informed advisory services

Department for International Development

digitalization for agriculture

Dutch Ministry for Foreign Affairs

Enhancing National Climate Services

Food and Agriculture Organization of the United Nations

Global Commission on Adaptation

Green Climate Fund

Global Based Information Services for

Small-Scale Farmers

Global Framework for Climate Services

Geodata for Agriculture and Water

Deutsche Gesellschaft für

Internationale Zusammenarbeit

Global System for Mobile Communications

International Center for Agricultural Research

in the Dry Areas

Inter-American Development Bank
IFPR I

IRI

IVR

LDCF

MCF

MEL

NACDC

NFCS

NMHS

Norad

PICSA

PPCR

PPP

RCT

RIMES

ROI

SDC

SMS

SOFF

UKAID

USAID

USSD

WBCSD

WFP

WMO
International Food Policy Research Institute International Research Institute for Climate and Society (Columbia University)

interactive voice response

Least Developed Countries Fund

Mastercard Foundation

monitoring, evaluation, and learning

National Agriculture Content Development

Committee (Malawi)

national framework for climate services

national meteorological and hydrological services

Norwegian Agency for Development Cooperation

Participatory Integrated Climate Services

for Agriculture

Pilot Program for Climate Resilience

public-private partnership

randomized control trial

Regional Integrated Multi-Hazard Early Warning System for Africa and Asia

return on investment

Swiss Development Cooperation

short message service

Systematic Observations Financing Facility

United Kingdom Agency for International Development

United States Agency for International Development

unstructured supplementary service data

World Business Council for Sustainable Development

World Food Programme

World Meteorological Organization 


\section{Endnote}

1 These estimates are based on a literature review from Tsan et al. (2021). There were assumed to be 190 million smallscale farmers and 60 million pastoralists in Africa during 2018. The projected growth rate was based on a Technical Centre for Agricultural and Rural Cooperation (CTA) survey in which participants reported a historical (three-year) annual growth rate of 44 percent in terms of their number of registered farmers. Participants estimated a future average growth rate of 55 percent over the next three years.

\section{References}

Abate, G.T., T. Bernard, S. Makhija, and D.J. Spielman. 2019. "Accelerating Technical Change through Video-Mediated Agricultural Extension: Evidence from Ethiopia." Discussion Paper 1851. Washington, DC: International Food Policy Research Institute. https://doi.org/10.2499/p15738coll2.133323.

Aryal, J., T. Sapkota, R. Khurana, A. Khatri-Chhetri, D.B. Rahut, and M.I. Jat. 2020. "Climate Change and Agriculture in South Asia: Adaptation Options in Small-Scale Production Systems." Environment, Development and Sustainability 22 (August): 5045-75. https://doi.org/10.1007/s10668-019-00414-4.

Avko Foundation. n.d. "Creating aSustainable Information Service for Coffee Farmers in Vietnam with GREENCoffee." https:// akvo.org/stories/south-east-asia-pacific/creating-a-sustainableinformation-service-for-coffee-farmers-in-vietnam-withgreencoffee/. Accessed May 3, 2021.

aWhere. 2020. "About Us." https://www.awhere.com/. Accessed March 15, 2020.

Barnston, A.G., and M.K. Tippett. 2014. "Climate Information, Outlooks, and Understanding-Where Does the IRI Stand?" Earth Perspectives 1 (20). https://doi.org/10.1186/2194-6434-1-20.

Birachi E., J. Hansen, M. Radeny, M. Mutua, M.W. Mbugua, Y. Munyangeri, A. Rose, et al. 2020. "Rwanda Climate Services for Agriculture: Evaluation of Farmers' Awareness, Use and Impacts." Working Paper 304. Wageningen, Netherlands: CGIAR Research Program on Climate Change, Agriculture and Food Security. https://hdl.handle.net/10568/108052.

Carr, E.R., and S.N. Onzere. 2017. "Really Effective (for 15\% of the Men): Lessons in Understanding and Addressing User Needs in Climate Services from Mali." Climate Risk Management 22: 82-95. https://doi.org/10.1016/j.crm.2017.03.002.

Chhabra, K. 2020. "First Aadhar Authenticated Digital Farmers Database 2020-21 in India for Agricultural Schemes." Sarkari Yojana, June 29. https://sarkariyojana.com/india-first-aadharauthenticated-digital-farmers-database/.

Cisco. 2020. (Database.) Global Digital Readiness Index 2019. https://www.cisco.com/c/en/us/about/csr/research-resources/ digital-readiness.html. Accessed October 23, 2020.
ClimDev-Africa (Climate for Development in Africa Programme). 2012. "ClimDev-Africa Programme: Work Plan for 2012-2014." https://www.afdb.org/fileadmin/uploads/afdb/Documents/ Procurement/Corporate-Procurement/ClimDev\%20Africa\%20 Work\%20Plan\%20for\%202012-2014\%20\%2816\%20Mar\%20 2012\%29.pdf.

Cole, S.A., and A.N. Fernando. 2016. "'Mobile'izing Agricultural Advice: Technology Adoption, Diffusion and Sustainability." Working Paper 13-047. Boston: Harvard Business School. https://www.hbs.edu/ris/Publication\%20Files/13047_155cb6a2-afb5-4744-a62d-929b01fc9e7c.pdf.

Digital Green. 2019. "About Us." https://www.digitalgreen.org/ about-us/. Accessed March 16, 2020.

Digital Public Goods Alliance. n.d. "Registry." https:// digitalpublicgoods.net/registry/. Accessed December 12, 2020.

EIP-AGRI (European Innovation Partnership-Agricultural Productivity and Sustainability). 2017. EIP-AGRI Focus Group Benchmarking of Farm Productivity and Sustainability Performance. Final Report. Brussels: EIP-AGRI. https://ec.europa. eu/eip/agriculture/sites/agri-eip/files/eip-agri_fg_benchmarking_ final_report_2016_en.pdf.

Esoko. 2020. "About Us." https://esoko.com/who-we-are/. Accessed March 16, 2020.

Fabregas, R., M. Kremer, and F. Schilbach. 2019. "Realizing the Potential of Digital Development: The Case of Agricultural Advice." Science 366 (6471). https://doi.org/10.1126/science. aay3038.

FAO (Food and Agriculture Organization of the United Nations). 2017. The Future of Food and Agriculture: Trends and Challenges. Rome: FAO. http://www.fao.org/3/i6583e/i6583e.pdf.

FA0. 2020a. Open Data Licensing for Statistical Databases: Policy. Rome: FAO. http://www.fao.org/3/ca7570en/ca7570en.pdf.

FA0. 2020b. Realizing the Potential of Digitalization to Improve the Agri-Food System: Proposing a New International Digital Council for Food and Agriculture-a Concept Note. Rome: FAO. http:// www.fao.org/3/ca7485en/ca7485en.pdf.

FA0, IFAD (International Fund for Agricultural Development), UNICEF (United Nations Children's Fund), WFP (World Food Programme), and WHO (World Health Organization). 2018. The State of Food Security and Nutrition in the World 2018: Building Climate Resilience for Food Security and Nutrition. Rome: FAO. http://www.fao.org/3/I9553EN/i9553en.pdf.

FAO, IFAD, UNICEF, WFP, and WHO. 2020. The State of Food Security and Nutrition in the World 2020: Transforming Food Systems for Affordable Healthy Diets. Rome: FA0. http://www.fao. org/3/ca9692en/ca9692en.pdf.

Fielke, S., B. Taylor, and E. Jakku. 2020. "Digitalisation of Agricultural Knowledge and Advice Networks: A State-of-the-Art Review." Agricultural Systems 180 (April): 102763. https://doi. org/10.1016/j.agsy.2019.102763. 
FutureWater. 2014. "Water and Climate Services for Transboundary Water Management and Disaster Risk Management." https://www.futurewater.eu/projects/water-andclimate-vietnam/.

G4AW (Geodata for Agriculture and Water). n.d.a. "CommonSense Ethiopia." Akvo Really Simple Reporting. https:// nso-g4aw.akvoapp.org/en/project/5297/. Accessed July 28, 2020

G4AW. n.d.b. "GEOBIS Bangladesh." Akvo Really Simple Reporting. https://nso-g4aw.akvoapp.org/en/project/5311/. Accessed July 28, 2020.

G4AW. n.d.c. "GEODATICS." Netherlands Space Office. https:// g4aw.spaceoffice.nl/en/g4aw-projects/g4aw-projects/14/ geodatics.html. Accessed July 28, 2020.

G4AW. n.d.d. "IDSS Bangladesh." Akvo Really Simple Reporting. https://nso-g4aw.akvoapp.org/en/project/5305/. Accessed July 28, 2020.

G4AW. n.d.e. "MODHEM Burkina Faso." Akvo Really Simple Reporting. https://nso-g4aw.akvoapp.org/en/project/5309/. Accessed July 28, 2020.

G4AW. n.d.f. "MUISS Uganda." Akvo Really Simple Reporting. https://nso-g4aw.akvoapp.org/en/project/5307/\#report. Accessed May 17, 2021.

G4AW. n.d.g. "MYVAS4AGRI Myanmar." Akvo Really Simple Reporting. https://nso-g4aw.akvoapp.org/en/ project/7122/\#report. Accessed July 21, 2020.

G4AW. n.d.h. "Sat4Rice Vietnam." Avko Really Simple Reporting. https://nso-g4aw.akvoapp.org/en/project/5302/. Accessed July 28, 2020.

G4AW. n.d.i. "SMARTseeds Indonesia." Akvo Really Simple Reporting. https://nso-g4aw.akvoapp.org/en/project/5310/. Accessed July 28, 2020.

GFCS (Global Framework for Climate Services). 2020. "Current Status of the Implementation of National Frameworks for Climate Services (NFCS)." World Meterological Organization. https://gfcs. wmo.int/NFCS_status.

GFRAS (Global Forum for Rural Advisory Services). 2021. "Mission \& Fields of Action." https://www.g-fras.org/en/about-us/ vision-mission.html.

GSMA (Global System for Mobile Communications). 2020. The Mobile Economy for Sub-Saharan Africa 2020. London: GSMA. https://www.gsma.com/mobileeconomy/wp-content/ uploads/2020/09/GSMA_MobileEconomy2020_SSA_Eng.pdf.

Gumucio, T., J. Hansen, S. Huyer, and T. van Huysen. 2020. "Gender-Responsive Rural Climate Services: A Review of the Literature." Climate and Development 12 (3): 24154. https://doi.org/10.1080/17565529.2019.1613216.
Hunter, M., G. Smith, M. Schipanski, L. Atwood, and A. Mortensen. 2017. "Agriculture in 2050: Recalibrating Targets for Sustainable Intensification." BioScience 67 (4): 386-91. https:// doi.org/10.1093/biosci/bix010.

IBM. 2019. "Emnotion Ltd." https://www.ibm.com/case-studies/ emnotion-cloud.

IFC (International Finance Corporation). 2019. Working with Smallholders: A Handbook for Firms Building Sustainable Supply Chains. Washington, DC: IFC. https://openknowledge.worldbank. org/handle/10986/29764.

ISF Advisors and Swiss Re. 2020. Strategies for Supporting Sustainable and Climate-Smart Advisory Services. Washington, DC: ISF Advisors; Zurich: Swiss Re Foundation. https://media. swissrefoundation.org/documents/Strategies+for+Supporting+Su stainable+and+Climate-Smart+Advisory+Services1.pdf.

Knox, J.W., A. Daccache, T.M. Hess, M. Else, M. Kay, M. Burton, D. Thelwall, and H. Malano. 2013. Benchmarking Agricultural Water Use and Productivity in Key Commodity Crops. Final Report WU0122. Cranfield, UK: Cranfield University.

Kristjanson, P., E. Bryan, Q. Bernier, J. Twyman, R. Meinzen-Dick, C. Kieran, C. Ringler, C. Jost, and C. Doss. 2017. "Addressing Gender in Agricultural Research for Development in the Face of a Changing Climate: Where Are We and Where Should We Be Going?" International Journal of Agricultural Sustainability 15 (5): 482-500. https://doi.org/10.1080/14735903.2017.1336411.

Landell Mills. 2019. Performance Evaluation of the New Alliance Information and Communication Technologies Agriculture Extension Challenge Fund. Final Report. London: Department for International Development. http://iati.dfid.gov.uk/iati_ documents/48674399.pdf.

Mercy Corps. 2017. "In Mongolia, Winter Looms on the Edge of the Earth." Mercy Corps Blog, October 15. https://www. mercycorps.org/blog/mongolia-winter-herders-technology.

Mercy Corps. 2020. "AgriFin." https://www.mercycorpsagrifin. org/.

Microsoft News Center. 2017. "Digital Agriculture: Farmers in India Are Using Al to Increase Crop Yields." November 7. https:// news.microsoft.com/en-in/features/ai-agriculture-icrisat-uplindia.

ND-GAIN (Notre Dame Global Adaptation Initiative). 2020. (Database.) ND-GAIN Country Index. University of Notre Dame. https://gain.nd.edu/our-work/country-index/. Accessed on October 23, 2020

Norton, G.W., and J. Alwang. 2020. "Changes in Agricultural Extension and Implications for Farmer Adoption of New Practices." Applied Economic Perspectives and Policy 42 (1): 8-20. https://doi.org/10.1002/aepp.13008. 
Nsengiyumva, G., D. Kagabo, Y. Munyangeri, and C. Mungai. 2018. "Rwandan Farmers Share How Climate Information Helps Them Improve Food Security." CGIAR Research Program on Climate Change, Agriculture and Food Security, September 13. https:// ccafs.cgiar.org/news/rwandan-farmers-share-how-climateinformation-helps-them-improve-food-security.

Ongus, E. 2020. "The Demand for Climate Informed Agricultural Services." Unpublished research.

People in Need. 2019. "People in Need and Mercy Corps Supported Herders in Mongolia in Disaster Risk Reduction through Early Warning SMS System and Capacity Building." June 24. https://www.clovekvtisni.cz/en/people-in-need-and-mercycorps-supported-herders-in-mongolia-in-disaster-risk-reductionthrough-early-warning-sms-system-and-capacity-building-5881gp.

Perez, C., E.M. Jones, P. Kristjanson, L. Cramer, P.K. Thornton, W. Förch, and C. Barahona. 2015. "How Resilient Are Farming Households and Communities to a Changing Climate in Africa? A Gender-Based Perspective." Global Environmental Change 34 (September): 95-107. https://doi.org/10.1016/j. gloenvcha.2015.06.003.

Larosa, F., and Perrels, A. 2017. Assessment of the Existing Resourcing and Quality Assurance of Current Climate Services. Lecce, Italy: Centro Euro-Mediterraneo sui Cambiamenti Climatici. http://eu-macs.eu/wp-content/uploads/2017/07/ EUMACS_D12_v2x.pdf.

Phatty-Jobe, A., A. Seth, and K. Norton. 2020. Digital Agriculture Maps: 2020 State of the Sector in Low and Middle-Income Countries. London: Global System for Mobile Communications. https://www.gsma.com/r/wp-content/uploads/2020/09/GSMAAgritech-Digital-Agriculture-Maps.pdf.

Raithatha, R., and J. Priebe. 2020. Agricultural Insurance for Small-Scale Farmers: Digital Innovations for Scale. London: Global System for Mobile Communications. https://www.gsma. com/mobilefordevelopment/wp-content/uploads/2020/05/ Agricultural_Insurance_for_Smallholder_Farmers_Digital_ Innovations_for_Scale.pdf.

Roy, S., and A. Rani. 2018. "Agromet Advisory for Empowering Farmers to Mitigate Climate Change." Biotech Articles, April 19. https://www.biotecharticles.com/Agriculture-Article/ Agromet-Advisory-for-Empowering-Farmers-to-Mitigate-ClimateChange-4396.html.

Rodrigues, J., J. Thurlow, W. Landman, C. Ringler, R.D. Robertson, and T. Zhu. 2016. "The Economic Value of Seasonal Forecasts Stochastic Economywide Analysis for East Africa." Discussion Paper 01546. Washington, DC: International Food Policy Research Institute. http://ebrary.ifpri.org/utils/getfile/collection/ p15738coll2/id/130497/filename/130708.pdf.

Safaricom. 2020. "About Us." https://www.safaricom.co.ke/ about/. Accessed March 16, 2021.
Sara, R., 2019. "Responsible Data Guidelines: Managing Privacy and Personally Identifiable Information in the Research Project Data Lifecycle." CGIAR Platform for Big Data in Agriculture. https://bigdata.cgiar.org/responsible-data-guidelines/.

Seid, J., K. Tesfaye, and P.C.S. Traore. 2019. Launch of the Ethiopian Digital AgroClimate Advisory Platform (EDACaP) Progress Report on EDACaP Development and Hosting. Wageningen, Netherlands: CGIAR Research Program on Climate Change, Agriculture and Food Security. https://hdl.handle. net/10568/107770.

Steiner, A., G. Aguilar, K. Bomba, J.P. Bonilla, A. Campbell, R. Echeverria, R. Gandhi, et al. 2020. Actions to Transform Food Systems under Climate Change. Wageningen, Netherlands: CGIAR Research Program on Climate Change, Agriculture and Food Security. https://hdl.handle.net/10568/108489.

Sulaiman, R., D. Chuluunbaatar, and S. Vishnu. 2018. Upscaling Climate Smart Agriculture: Lessons for Extension and Advisory Services. Technical Report. Rome: Food and Agriculture Organization of the United Nations. http://www.fao.org/3/ i9209en/l9209EN.pdf.

Tall, A., J.Y. Coulibaly, and M. Diop. 2018. "Do Climate Services Make a Difference? A Review of Evaluation Methodologies and Practices to Assess the Value of Climate Information Services for Farmers: Implications for Africa." Climate Services 11 (August): 1-12. https://doi.org/10.1016/j.cliser.2018.06.001.

Tsan, M., S. Totapally, M. Hailu, and B.K. Addom. 2021. The Digitalisation of African Agriculture Report 2018-2019. Wageningen, Netherlands: Technical Centre for Agricultural and Rural Cooperation/Dalberg Advisers. https://www.cta.int/en/ digitalisation-agriculture-africa.

UNFCCC (United Nations Framework Convention on Climate Change). 2018. Developing and Enhancing Endogenous Capacities and Technologies: Technology Stakeholders' Perspectives: Technology Stakeholders' Perspectives. Bonn, Germany: Technology Executive Committee, UNFCCC. https://unfccc.int/ ttclear/misc_/StaticFiles/gnwoerk_static/endogenous_index/783 d7125afec404da1bef315fe3be600/861a47c1627244deabca4b12 e949ebfa.pdf.

University of Reading. n.d. "PICSA in Practice." https://research. reading.ac.uk/picsa/picsa-practice/. Accessed December 10, 2020.

USAID (United States Agency for International Development). 2015. "Project Concern International: Satellite Technology to Improve Pastoral Decision Making." https://www.usaid.gov/div/ portfolio/pci-pastoralists.

Usher, J., C. Phiri, N. Linacre, R. O'Sullivan, and U. Qadir. 2018. Climate Information Services Market Assessment and Business Model Review. Review prepared for USAID. Arlington, VA: Winrock International. 
van Schalkwyk, F., A. Young, and S. Verhulst. 2017. Ghana: Esoko-Leveling the Information Playing Field for Small-Scale Farmers in Ghana. New York: Open Data's Impact. https://esoko. com/wp-content/uploads/2019/07/0di_case-esoko.pdf.

Venkatasubramanian, K., A. Tall, J. Hansen, and P. K. Aggarwal. 2014. "Assessment of India's Integrated Agro-meteorological Advisory Service Program from a Farmer Perspective." Working Paper 54. Copenhagen, Denmark: CGIAR Research Program on Climate Change, Agriculture and Food Security. https://hdl. handle.net/10568/43733.

WBCSD (World Business Council for Sustainable Development). 2021. Digital Climate Advisory Services (DCAS) for Small-Scale Resilience: Opportunities and Challenges to Scale to 300 Million Farmers. Geneva: WBCSD. https://www.wbcsd.org/download/ file/11227.

WBG (World Bank Group). 2019. Cote d'Ivoire Climate-Smart Agriculture Investment Plan. Washington, DC: World Bank. https:// openknowledge.worldbank.org/handle/10986/32745.

WFP (World Food Programme). 2018. Mongolia Annual Country Report 2018. Rome: WFP. https://docs.wfp.org/api/documents/ WFP-0000104276/download/.

WFP. 2020. WFP Global Update on COVID-19: November 2020Growing Needs, Response to Date and What's to Come in 2021. Rome: WFP. https://reliefweb.int/sites/reliefweb.int/files/ resources/WFP-0000121038.pdf.

White, J.W., L.A. Hunt, K.J. Boote, J.W. Jones, J. Koo, S. Kim, C.H. Porter, P.W. Wilkens, and G. Hoogenboom. 2013. "Integrated Description of Agricultural Field Experiments and Production: The ICASA Version 2.0 Data Standards." Computers and Electronics in Agriculture 96 (August): 1-12. https://www.sciencedirect.com/ science/article/pii/S016816991300077X.

Wilkinson, M.D., M. Dumontier, I. Aalbersberg, et al. 2016. "The FAIR Guiding Principles for Scientific Data Management and Stewardship." Scientific Data 3 (March): 160018. https://doi. org/10.1038/sdata.2016.18.

WMO (World Meteorological Organization). 2012. Rev. ed. Guide to Agricultural Meteorological Practices. Report 134. Geneva: WMO. https://library.wmo.int/doc_num.php?explnum_id=3996.

WMO. 2014a. Climate Data Management System Specifications: Version 1.0. Geneva: WMO. https://library.wmo.int/doc_num. php?explnum_id=7867.

WMO. 2015. Valuing Weather and Climate: Economic Assessment of Meteorological and Hydrological Services. Report 1153. Geneva: WMO. https://library.wmo.int/doc_num.php?explnum_ id $=3314$.
WMO. 2018. Guidelines on Quality Management in Climate Services. Report 1221. Geneva: WMO. https://library.wmo.int/ doc_num.php?explnum_id=5174.

WMO. 2019. 2019 State of Climate Services: Agriculture and Food Security. Report 1242. Geneva: WMO. https://library.wmo.int/ doc_num.php?explnum_id=10089.

WMO. 2020. Guidance on Operational Practices for Objective Seasonal Forecasting. Report 1246. Geneva: WMO. https://library. wmo.int/doc_num.php?explnum_id=10314.

Wolfert, S., L. Ge, C. Verdouw, and M. Bogaardt. 2017. "Big Data in Smart Farming-a Review." Agricultural Systems 153 (May): 69-80. https://doi.org/10.1016/j.agsy.2017.01.023.

World Bank. 2020. (Database). World Bank Country and Lending Groups. Washington, DC: World Bank. https://datahelpdesk. worldbank.org/knowledgebase/articles/906519-world-bankcountry-and-lending-groups. Accessed October 23, 2020.

Zhao, C., B. Liu, S. Piao, X. Wang, D.B. Lobell, Y. Huang, M. Huang, et al. 2017. "Temperature Increase Reduces Global Yields of Major Crops in Four Independent Estimates." Proceedings of the National Academy of Sciences of the United States of America 114 (35): 9326-31. https://doi.org/10.1073/pnas.1701762114.

\section{Acknowledgments}

The Managing Partners of the Commission, GCA and WRI, are pleased to acknowledge the institutional strategic partners that provide crucial funding for this work: the Department for International Development of the United Kingdom (or should we say FCDO, United Kingdom), Environment and Climate Change Canada, the Federal Ministry for Economic Cooperation and Development of Germany, the Netherlands Ministry of Infrastructure and Water Management and the Ministry of Foreign Affairs, the Royal Danish Ministry of Foreign Affairs, the Swedish International Development Cooperation Agency and the Bill and Melinda Gates Foundation. 


\section{About the Authors}

Tyler Ferdinand is a Research Associate with the Climate Resilience Practice at WRI. His work focuses on adaptation limits, resilience transition pathways, and equitable socioeconomic shifts.

Contact: tyler.ferdinand@wri.org

Emma Illick-Frank is a Research Analyst with the Climate Resilience Practice at WRI. Her work focuses on locally led adaptation to climate change and long-term national adaptation efforts.

Contact:emma.illick-frank@wri.org

Louise Postema is Program Officer Strategy at the Global Center on Adaptation. She supports the development and coordination of the Center's programs, including its Rural Well-being and Food Security Program.

Contact: louise.postema@gca.org

Jim Stephenson is the Director and Co-Founder of Terranomics, a consultancy focused on scaling up private investment to address sustainable land-use and climate change challenges.

Contact: jim.stephenson@terranomics.org

Alison Rose is a Program Manager at Columbia University's International Research Institute for Climate and Society. Her work is at the intersection of climate, agriculture, and food security in developing countries.

Contact: arose@iri.columbia.edu

Darko Petrovic is a vulnerability analyst and focal point for demand side research on digital financial inclusion and women economic empowerment in the context of climate hazards at the World Food Programme in the Caribbean.

Contact: darko.petrovic@wfp.org

Claude Migisha is a Digital Development Expert currently working with the Global Center on Adaptation to scale-up access to Digital Climate Advisory Services, associated data-driven agricultural and financial services to improve food systems outcomes and strengthen the resilience of small-scale producers in the global south.

Contact: Claude.migisha@gca.org
Katiuscia Fara, is a Senior Climate and Disaster Risk Reduction Advisor with the World Food Programme in the Asia Pacific region. Her work has focused on climate and disaster risk management, sustainable development, poverty reduction and community-based adaptation.

Contact: katiuscia.fara@wfp.org

Stephen Zebiak is Special Research Scientist with the International Research Institute for Climate and Society (IRI), and is currently the leader of the CCAFS Flagship Program on Climate Services and Safety Nets. In various roles over more than three decades, he has worked in climate research, climate prediction, and climate services.

Contact: steve@iri.columbia.edu

Tony Siantonas is Director of Scaling Positive Agriculture at the World Business Council for Sustainable Development (WBCSD), leading on sustainable agricultural initiatives to address climate change, natural resources, finance mobilization and innovation.

Contact: siantonas@wbcsd.org

Nicoletta Pavese is Manager of the Soft Commodities Forum at the World Business Council for Sustainable Development, leading pre-competitive collaboration in the agribusiness sector for sustainable, and deforestation free supply chains.

Contact:pavese@wbcsd.org

Tom Chellew is an Associate at Terranomics, where he manages and provides research support to projects focusing on private sector engagement in sustainable land-use and climate change.

Contact: tom.chellew@terranomics.org

Bruce Campbell is a Senior Advisor with the Global Center on Adaptation and Director of the CGIAR Research Program on Climate Change, Agriculture and Food Security. He works on climate change adaptation and mitigation in food systems of the Global South.

Contact: b.campbell@cgiar.org

Cristina Rumbaitis del Rio is a Senior Adaptation and Resilience Advisor at the World Resources Institute and International Engagement Associate at the Food and Landuse Coalition. She works on adaptation policies, food system resilience, and locally led adaptation.

Contact: Cristina.RdelRio@WRI.org 
WORLD

RESOURCES

INSTITUTE
GLOBAL

CENTER ON

ADAPTATION 